\title{
Circe y las sirenas: de la épica griega al microrrelato hispanoamericano
}

\author{
Aurora Galindo Esparza ${ }^{1}$
}

Recibido: 24 de octubre de 2016 / Aceptado: 11 de diciembre de 2016

Resumen. Este trabajo analiza la vigencia de las aventuras homéricas de Circe y las sirenas en el microrrelato hispanoamericano. Para ello, partimos de la épica griega arcaica para hacer un acercamiento a la tradición de estos temas odiseicos, tratando de detectar los principales hitos literarios que pueden haber influido de forma directa o indirecta en la narrativa ultrabreve posmoderna. A continuación, recogemos y comentamos una muestra de microrrelatos inspirados en los temas de Circe y las sirenas que nos permiten extraer unas conclusiones generales acerca de la pervivencia de estos motivos homéricos en la microficción americana contemporánea.

Palabras clave: literatura griega; Odisea; microrrelato; mitología clásica; Circe; sirenas; literatura comparada; intertextualidad; pervivencia de Homero; Posmodernidad literaria.

\section{[en] Circe and the Sirens: from Greek epic to Hispanic American microfiction}

\begin{abstract}
This paper analyzes the continuity of the Homeric adventures of Circe and the sirens in Hispanic American microfiction. To do this, we depart from Greek Archaic epic to make an approach to the tradition of these Odyssean topics, trying to detect major literary milestones that may have influenced directly or indirectly Postmodern flash fiction. Then we choose and comment a sample of micro-stories inspired by the episodes of Circe and the sirens, which allow us to draw general conclusions about the survival of these Homeric motifs in contemporary Hispanic American microfiction.
\end{abstract}

Keywords: Greek literature; Odyssey; microfiction; classical mythology; Circe; sirens; comparative literature; intertextuality; pervivence of Homer; literary Postmodernism.

Sumario. 1. Los episodios de Circe y las sirenas. 2. El microrrelato y la intertextualidad. 3. Microrrelatos sobre Circe y las sirenas. 3.1. Sirenas silenciosas: variaciones de Torri. 3.2. Circe amante y maga. 3.3. Sirenas antiguas y nuevas sirenas. 4. Conclusiones.

Cómo citar: Galindo Esparza, A. (2017) Circe y las sirenas: de la épica griega al microrrelato hispanoamericano, en Cuadernos de Filología Clásica. Estudios griegos e indoeuropeos 27, 235-265.

$1 \quad$ Universidad de Murcia.

E-mail: age4@um.es 
Estas páginas analizan la vigencia de los mitos homéricos de Circe y las sirenas en una forma literaria que se acuña en el siglo xx y se erige como una de las más representativas de las letras de Hispanoamérica: el microrrelato.

En un trabajo anterior ${ }^{2}$ realizamos un primer acercamiento a los microcuentos hispanoamericanos de inspiración odiseica. El presente artículo pretende desarrollar el examen de estos tratamientos, ejemplos vivos y recientes de la pervivencia de Homero en la literatura hispánica. Nos ocupamos conjuntamente de las aventuras de Odiseo con Circe y con las sirenas porque en el microcuento ambos episodios tienden a solaparse: ya en la Odisea estaban relacionados, y algunas obras ilustres de la tradición posterior reforzaron ese vínculo.

La recepción contemporánea de la Odisea se presenta matizada y enriquecida con una larga tradición de revisiones que comienza en la antigua Grecia. Los mitos griegos, patrimonio cultural de los pueblos de Occidente, se adaptan durante siglos a todos sus contextos culturales, siempre abiertos a nuevas lecturas artísticas, ideológicas o filológicas. Desde la propia Antigüedad la literatura se nutre de relatos mitológicos, enseguida despojados de su valor religioso. Por ello, las recreaciones posmodernas de Homero incorporan aportaciones y variaciones de autores como Virgilio, Ovidio, Dante, Fray Luis, Kafka o Joyce. Ofrecemos un bosquejo de obras de distintos periodos que pueden haber influido directa o indirectamente en los relatos hiperbreves que hemos escogido.

Los microcuentos atrapan instantes de la épica, género por definición extenso y grave, dentro de un esquema ligero y extremadamente breve. Así un mismo asunto, las peripecias fantásticas de la navegación de Odiseo, se proyecta en modalidades literarias en principio antagónicas. La épica es además un género de larguísima tradición, y la Ilíada y la Odisea, los textos más antiguos de la literatura occidental, mientras que la microficción es una de las producciones más flamantes del siglo xx. Lo que sí comparten épica y microcuento es su atracción por la fantasía y los hechos maravillosos, de los que Circe y las sirenas, seres femeninos sobrenaturales, son figuras emblemáticas.

\section{Los episodios de Circe y las sirenas}

Procedemos a continuación a repasar los elementos primordiales de la tradición de las aventuras de Circe y las sirenas desde Homero: ambas leyendas hunden sus raíces en el folklore oriental, cuyos motivos habían pasado a la épica griega arcaica, y allí se habían ajustado a un patrón más sobrio y menos fantástico.

El episodio de Circe ocupa casi la totalidad del Canto X de la Odisea - del v. 135 hasta el final-y concluye en el Canto XII. Huyendo de Lestrigonia, Odiseo y sus hombres van a parar a otro enclave peligroso, la isla de «Circe de bellos rizos,

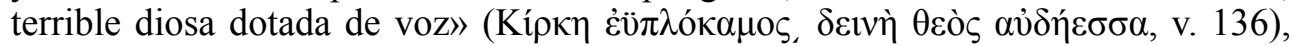
hija de Helios y de la oceánide Perse y hermana por tanto del cruel Eetes, rey de los colcos y padre de Medea (vv. 137-139).

2 Galindo Esparza (2015) El tema de Circe en la tradición literaria: de la épica griega a la literatura española, Murcia. 
La parte introductoria (vv. 135-186) que describe la llegada a Eea va creando un clima de suspense que alcanzará su culmen con la metamorfosis en cerdos de los hombres de Odiseo. El héroe avista humo en el bosque y envía un grupo capitaneado por Euríloco a explorar. Circe hace su aparición en el v. 210: los griegos encuentran su palacio en mitad del bosque, rodeado de lobos y leones que actúan como perros domesticados, pues la diosa los ha hechizado con pócimas maléficas (v. 213) . Los $^{3}$ viajeros escuchan el canto de Circe, tan bello que se preguntan si será mujer o diosa

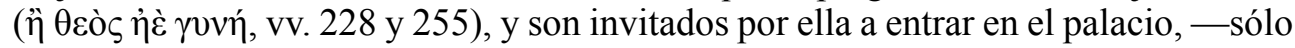
Euríloco desconfía y se niega - y beber un brebaje que contiene «pócimas funestas»

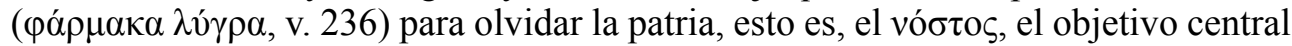
de la Odisea ${ }^{4}$. Acto seguido, Circe los golpea con su varita y los transforma en cerdos:

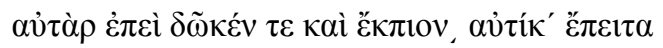

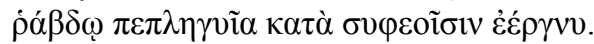

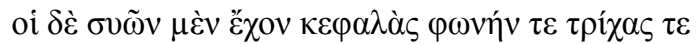

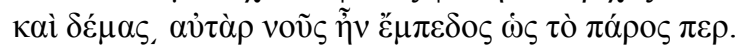

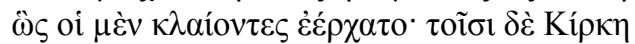

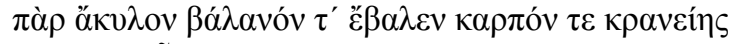

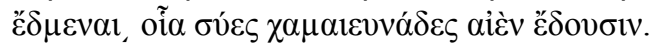

Od. X 237-243

Cuando se lo dio y lo bebieron, entonces

tras haberlos golpeado con la varita los encerró en pocilgas.

Y éstos tenían cabeza, voz, pelambre

y cuerpo de cerdos, pero su mente quedó inalterable, como antes.

Así quedaron encerrados llorando, y Circe les echó de comer

bellotas, fabucos y el fruto del cornejo,

las cosas que comen los cerdos que duermen en el suelo.

Cuando Odiseo acude al palacio a rescatar a sus hombres, Hermes aparece en su camino y le entrega un antídoto que lo hará inmune a los hechizos: el $\mu \tilde{\omega} \lambda v$, una planta de raíz negra y flor blanca (X 275-309). A esto le siguen la victoria de Odiseo y la rendición de Circe (309-405): la diosa no consigue hechizarlo y se postra a sus pies, lo reconoce como el afamado guerrero Odiseo, cuya llegada le había sido profetizada, y lo invita a acostarse con ella, comprometiéndose bajo juramento a no dañar su hombría ${ }^{5}$. Después devuelve la forma humana a los compañeros transformados.

Los griegos permanecen un año disfrutando de la hospitalidad de Circe (X 406-

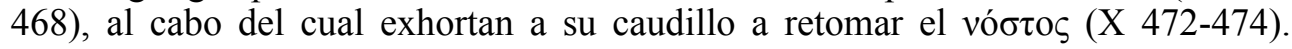
Cuando Odiseo pide a la diosa que lo deje marchar, ella anuncia que para volver a casa tendrá que pedir una profecía al alma del adivino Tiresias, que está en el Hades,

3 Es dudoso si se trata de fieras reducidas a la mansedumbre por medio de la magia o de hombres convertidos en bestias. Euríloco más adelante advierte que Circe podría convertirlos «en cerdos o lobos o leones» (v. 433).

4 La amenaza del olvido recorre toda la epopeya bajo diversas formas: la seducción de Calipso, el loto de los Lotófagos, la pócima de Circe, el canto de las sirenas... Pero el fin del ataque mágico de Circe no queda claro, pues no altera las mentes de los griegos, y por tanto no se daría tal olvido.

5 Circe garantiza con «el gran juramento de los dioses felices» ( $\mu \alpha \kappa \alpha ́ \rho \omega \nu ~ \mu \varepsilon ́ \gamma \alpha \nu$ ó $\kappa o v$, vv. 299 y 343), esto es, el

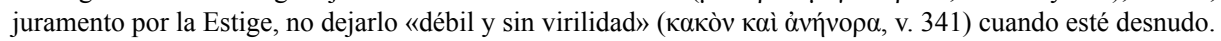


y le proporciona todas las indicaciones para la ceremonia infernal ${ }^{6}$. Circe colabora con los preparativos de la partida y cuando todo ha sido dispuesto desaparece de la playa de Eea sin que nadie lo perciba.

Circe no interviene en el Canto XI, pero Odiseo, empujado por un viento favorable enviado por ella, llega al lugar indicado, y allí realiza la véкvı (vv. XI 1-50) siguiendo punto por punto las instrucciones que la diosa pronuncia en la prolepsis de X 490-540.

Cumplido el ritual, los itacenses retornan a Eea, donde de nuevo reciben ayuda de Circe (XII 1-152) y otra profecía para continuar el viaje, en un nuevo discurso programático que anticipa sucesos que se desarrollan a continuación: la navegación sorteando los peligros de las sirenas, Escila y Caribdis y Trinaquia (XII 39-141/

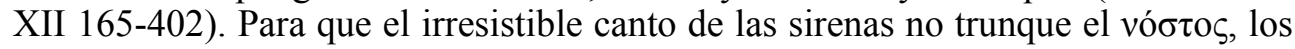
griegos deben tapar sus oídos y atar a Odiseo al mástil.

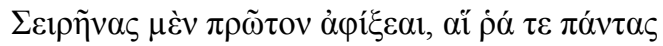

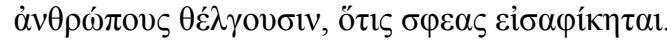

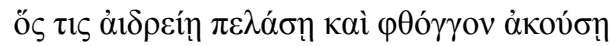

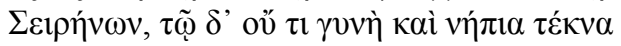

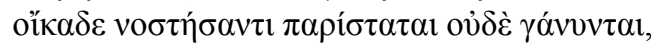

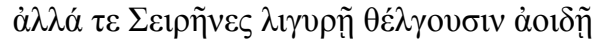

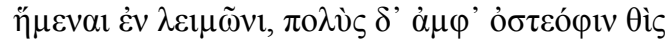

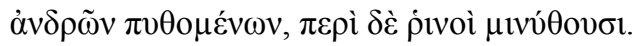

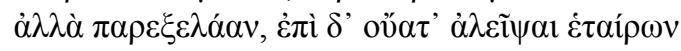

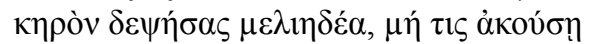

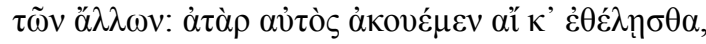

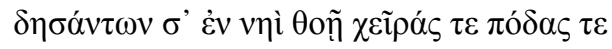

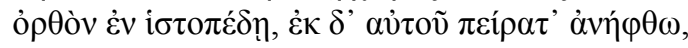

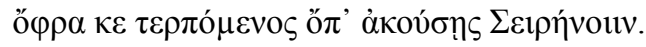

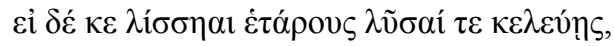

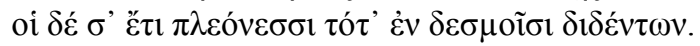

Od. XII 39-54

Primero llegarás a las sirenas, que a todos los hombres que se acercan a ellas hechizan. El que por ignorancia se aproxima y escucha el sonido de las sirenas, a éste nunca su mujer y sus hijos pequeños lo rodean y se alegran cuando vuelve a casa, sino que las sirenas lo hechizan con su sonoro canto, sentadas en un prado, y alrededor un enorme cúmulo de huesos de hombres podridos, y sus pieles se consumen en torno. Pero tú pasa de largo y tapa los oídos de tus compañeros Tras haber moldeado blanda cera, para que ninguno de ellos las oiga: mas si tú quieres escucharlas,

\footnotetext{
6 La visita al infierno es un motivo común en la épica. Odiseo realiza una invocación a los difuntos (vékvi $\alpha)$ y no

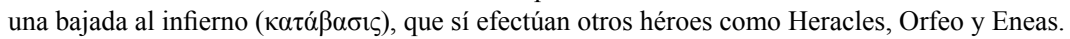


que te aten en la rápida nave de pies y manos

firme en la base del mástil, y que las sogas se liguen allí, para que deleitándote escuches la voz de las sirenas.

Y si suplicas y ordenas a tus compañeros que te desaten, que te amarren ellos con más ataduras todavía.

Al llegar el amanecer, Odiseo se hace a la mar y transmite a sus hombres las instrucciones de Circe: deben evitar «el canto de las divinas sirenas» y su «florido

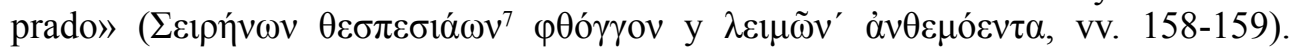
Concluye así la actuación de Circe en la Odisea, aunque sus profecías se siguen cumpliendo a lo largo del Canto XII. Si en el episodio de las sirenas los viajeros siguen al pie de la letra las pautas de Circe y escapan ilesos, en los sucesivos sufren las consecuencias de desoír sus órdenes ${ }^{8}$.

El encuentro con las sirenas es bastante breve (XII 165-200). Cuando se acercan a su isla, cesa el viento favorable que había mandado Circe y se hace una calma sobrenatural (vv. 168-169). Tal y como Circe había indicado, Odiseo tapa con cera los oídos de los tripulantes y ellos lo amarran en el mástil. Cuando las sirenas perciben

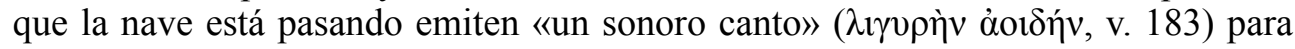
Odiseo, el único que puede oírlas:

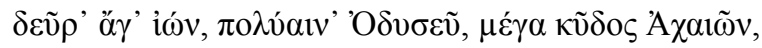

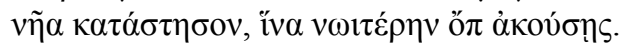

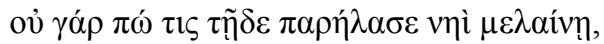

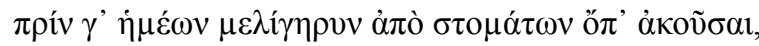

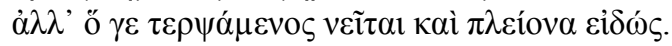

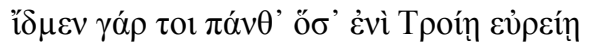

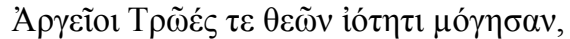

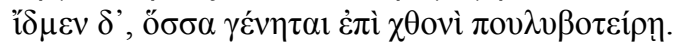

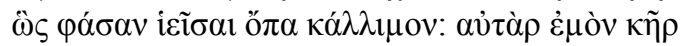

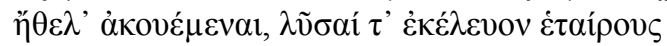

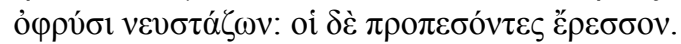

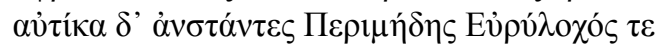

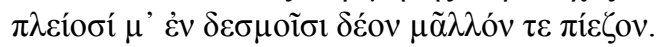
Od. XII 184-196

¡Vamos, ven aquí, famoso Odiseo, gran gloria de los aqueos!

Trae a tierra tu nave para que puedas escuchar nuestra voz.

Pues todavía nadie ha pasado de largo en su negra nave

sin escuchar la voz de dulce sonido de nuestras bocas, sino que se van después de haberse deleitado y sabiendo más cosas.

Porque ciertamente sabemos todas las cosas que sufrieron en la vasta Troya argivos y troyanos por la voluntad de los dioses, y sabemos cuanto ocurre sobre la tierra fecunda.

7 El epíteto $\theta \varepsilon \sigma \pi \varepsilon ́ \sigma 10 \varsigma-\alpha$-ov («de sonido divino») recalca su condición sobrenatural.

8 Odiseo se queda contemplando a Caribdis y trata de enfrentarse a Escila, que le arrebata a seis hombres. En Trinaquia los compañeros comen de los rebaños sagrados de Helios, provocándose una tempestad donde todos mueren salvo Odiseo, que naufraga en la isla de Calipso y allí, como había dicho Circe, pasa largos años (Od. I y V). 


\begin{abstract}
Así dijeron lanzando su hermosa voz: entonces mi corazón deseó escucharlas, y ordené a mis compañeros que me desataran moviendo las cejas; pero ellos inclinándose hacia delante remaban. Inmediatamente levantándose Euríloco y Perimedes me amarraron con más ataduras y me apretaron más.
\end{abstract}

Hay, pues, en Homero escasa información sobre las sirenas. Por el uso del dual femenino, sabemos que son dos y hembras, y que tienen dotes adivinatorias, pero nada más se dice'. Odiseo, atraído por su hermosa voz, pide por gestos que lo liberen, pero sus hombres lo atan más fuerte y se alejan de la isla. De este modo escapan los griegos de las criaturas cantoras.

En la epopeya Circe, las sirenas y también la ninfa Calipso, figuras femeninas maléficas, presentan concomitancias: oscilan entre el mundo acuático y terrestre; habitan islas lejanas ${ }^{10}$; tienen una naturaleza híbrida de humano y animal (las sirenas son mujeres-pájaro, la cueva de Calipso está rodeada de aves, y el nombre

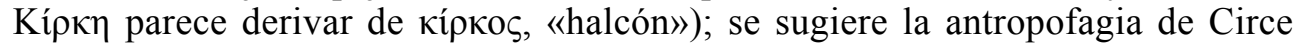
(transforma hombres en cerdos y los engorda en pocilgas) y de las sirenas (se sientan en un prado cubierto de huesos humanos); poseen el poder de hechizar (en los tres episodios se emplea el verbo $\theta \varepsilon \dot{\lambda} \gamma(\omega)$, y sus voces suscitan una atracción que se pone en relación con el olvido del vó $\sigma \tau \varsigma^{11}$. Estos paralelismos esbozados en Homero se intensificarán en los autores posteriores, que acentuarán igualmente la feminidad de estas figuras.

Las sirenas de la Odisea son un peligro sobrenatural e inhumano, equiparable a Escila o Caribdis, pero Circe desempeña un papel más complejo y ambiguo debido a la alternancia de tres funciones en su personaje: oponente del héroe, amante y profetisa. Su actuación inicial responde al primero de estos roles: convierte en cerdos a los viajeros y obstaculiza el vóotos en la misma medida que las sirenas. Estas sirenas, con las que ni siquiera hay contacto visual, carecen de las connotaciones eróticas que les serán asignadas después. En cuanto a Circe, su belleza se presupone por su condición divina, y su papel de amante de Odiseo le viene impuesto por la imposibilidad de someterlo. A diferencia de Calipso, que se resiste a dejar marchar a Odiseo cuando los dioses lo ordenan (V 118-144, 203-213), la indolente Circe lo deja ir dos veces, pronunciando en cada ocasión instrucciones para el viaje y nunca despedidas. Por último, el conocimiento de

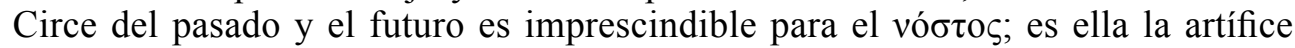
del ardid para escuchar a las sirenas sin caer en su trampa. También éstas poseen dotes proféticas y, al igual que Circe, reconocen a Odiseo porque saben «todo lo que ocurre sobre la fértil tierra» (XII 181). No tientan a los navegantes con su belleza, sino con el conocimiento: quienes escuchan su canto se van «sabiendo

9 Sobre el número de sirenas — que suele oscilar entre dos y cuatro—, sus nombres y su genealogía, los antiguos dan diversas versiones; $c f$. Jiménez San Cristóbal (2012: 117-122).

10 Esto puede aludir a una relación simbólica con el más allá; véase Marinatos (1995: 133-140; sobre Circe) y Jiménez San Cristóbal (2012: 142-147, para las sirenas).

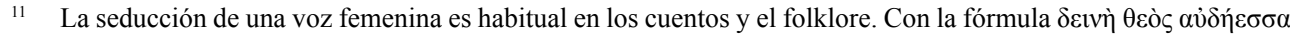
(«terrible diosa dotada de voz») son designadas Circe (X 136, XI 8 y XII 150) y Calipso (XII 449). La de Eea canta $\lambda$ í $\alpha$ («de forma armoniosa o sonora», X 254), adverbio de la raíz del adjetivo $\lambda$ ıүopós, que se aplica a las sirenas (XII 44, 183) y a la cítara del aedo Demódoco (VIII 67, 105, 254, 261, 537), que hace llorar a Odiseo. 
más cosas» (XII 188); es llamativo que a Odiseo traten de atraerlo contándole sus propias gestas ${ }^{12}$.

Fuera de Homero, otros héroes de la épica tienen encuentros con Circe y las sirenas. En las Argonáuticas de Apolonio de Rodas ${ }^{13}$, Circe es una figura

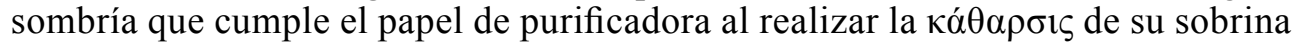
Medea y de Jasón por el asesinato del hermano de la princesa de la Cólquide (A.R IV 659-752). Al abandonar Eea, como en la Odisea, los argonautas pasan frente a las sirenas, y escapan gracias a Orfeo, que neutraliza su hechizo con su propio canto mágico y su lira (IV 885-921). Apolonio mantiene la exigua información homérica sobre las sirenas ${ }^{14} \mathrm{y}$ añade otros datos: el nombre de su

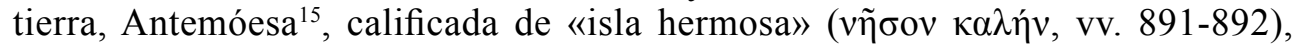
su genealogía (hijas de Aqueloo y la Musa Terpsícore, vv. 895-896), su antigua condición de compañeras de Perséfone (vv. 896-898) y su aspecto híbrido de mujeres-ave ${ }^{16}$.

El Eneas de Virgilio navega por muchos enclaves de la épica de viajes griega pero esquiva las islas de las sirenas y de Circe. En el primer episodio (Aen. V 854-868) el timonel se duerme y cae al mar, y Eneas logra controlar la embarcación a punto de zozobrar hacia la isla de las sirenas, descrita en un solo verso: «los escollos de las sirenas (...) en otro tiempo arduos y blancos por los huesos de muchos» (scopulos Sirenum [...] difficilis quondam multorumque ossibus albos, IV 864-865). El adverbio quondam ubica el peligro en el pasado, y apunta a una tradición mitográfica que refiere el suicidio de las sirenas tras la evasión de Odiseo ${ }^{17}$. En otra secuencia (VII 10-24), Neptuno envía un viento que aparta a los troyanos de Eea, donde se oyen el «canto constante» de Circe (adsiduo cantu, v. 12) y el bramido de sus fieras (vv. 15-18). Virgilio acentúa los rasgos tenebrosos de la «diosa cruel» (dea saeua, v.

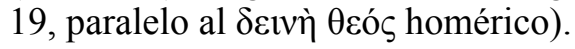

Muchos autores de la Antigüedad hicieron aproximaciones a estos temas desde diversas ópticas. Sin pretender ser exhaustivos, comentamos los aspectos más significativos de la andadura literaria de los episodios de Circe y las sirenas. De ellas seguirán figurando en primer plano sus cualidades mágicas y peligrosas, como desafío a la excelencia de Odiseo, pero paralelamente se van a reforzar sus rasgos femeninos y humanos, lo que no impide que por lo general se difuminen los

\footnotetext{
Cicerón comenta que atraen a los hombres «con el deseo de saber» (discendi cupiditate, Fin. V, XVIII 49)

Varios peligros de la Odisea (sirenas, Simplégades) estarían ya en la leyenda de los argonautas, saga mítica anterior a la de la guerra de Troya.

14 Repite términos homéricos $\lambda i ́ \gamma \varepsilon ı \alpha$ (Od. X 254 y XII 183 / A.R. IV 886) y $\theta \varepsilon ́ \lambda \gamma \omega$ (Od. XII 40 / A.R. IV 894),

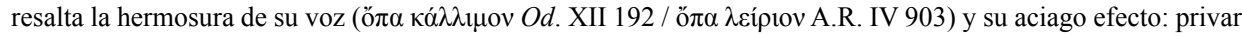

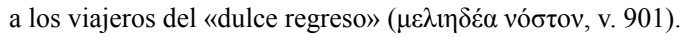

15 Apolonio toma el nombre de Hesíodo, fr. 27: A $v \theta \varepsilon \mu o ́ \varepsilon \sigma \sigma \alpha-\eta \varsigma$ («Florida»). El mismo término aparecía en Homero como adjetivo $\alpha \dot{v} \theta \varepsilon \mu o ́ \varepsilon ı \varsigma-\varepsilon \sigma \sigma \alpha-\varepsilon v ; \lambda \varepsilon \iota \mu \tilde{\omega} v^{\prime} \dot{\alpha} v \theta \varepsilon \mu o ́ \varepsilon v \tau \alpha$ («prado florido» Od. XII 158-159).

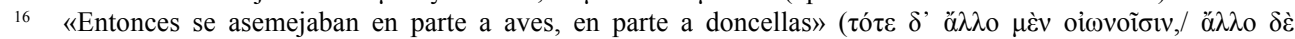

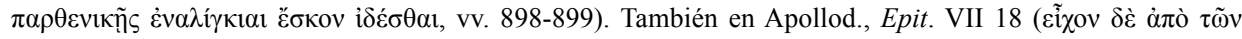

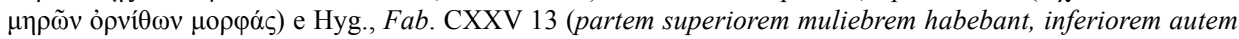
gallinaceam).

17 Entre otras fuentes, está en Apollod. Epit., VII 19 y en Hyg., Fab. CXXV, 13 y CXLI.
} 
caracteres positivos que tenía la diosa de Eea en Homero ${ }^{18}$. Quedan casi olvidadas las dotes proféticas y la omnisciencia que la épica atribuyó a ella y a las sirenas.

Ciertas obras enfatizan los sentimientos de Circe hacia Odiseo y le transfieren rasgos de la Calipso homérica y de la Dido virgiliana, que sufrían al verse abandonadas por Odiseo y Eneas. En la propia Odisea, aunque sólo Calipso trata de evitar la partida de Odiseo (Od. V 118-144, 203-213), el protagonista cuenta a los feacios que lo retuvieron Circe y Calipso queriendo convertirlo en su esposo (Od. IX 29-32). Las adaptaciones eróticas del episodio de Circe, pues, proceden de la contaminatio de la Odisea con la Eneida, que en el libro IV narraba el idilio de la reina Dido y el troyano Eneas. Virgilio había construido a su Dido con rasgos de varias figuras: las homéricas Circe, Calipso y Nausícaa y las Medeas de Eurípides y Apolonio.

En esta línea destacan las Metamorfosis, obra mitológica de referencia en Europa durante siglos. Ovidio, influido por el espíritu del epilio alejandrino, acentúa los aspectos eróticos de los mitos, aplica una mirada distanciadora y da un papel preponderante a la psicología femenina. La Circe de las Metamorfosis (XIII 898XIV 74 y XIV 241-440) es una maga ardiente y celosa, semejante a Medea, que lanza terribles conjuros cuando se ve despreciada por sus amantes. En Remedia Amoris (263-288) se convierte en una mujer enamorada y abandonada, pero aquí se mitigan su fiereza y el poder de su magia, que no le sirve para recuperar a Ulises ${ }^{19}$. Respecto a las sirenas (Met. V 552-563) Ovidio sigue a Apolonio y añade que fueron doncellas compañeras de Prosérpina (ya en Eurípides, Hel. 169-179); cuando ésta fue raptada la buscaron por el mundo entero y los dioses les concedieron alas para que cantaran su pena también en el $\operatorname{mar}^{20}$.

Las sirenas, más próximas en su naturaleza a animales o monstruos, no se revisten normalmente en los textos de este tamiz sentimental que ocasionalmente puede presentar Circe.

El patrón general en las relecturas de $O d$. X y $O d$. XII será la interpretación de Circe y las sirenas como representaciones de las tentaciones o placeres perniciosos - generalmente la sensualidad - que desvían al hombre del camino recto.

Tendrá gran peso en la literatura posterior un breve pasaje de Horacio (Ep. I 2, 2326) que relaciona «los cantos de las sirenas y las copas de Circe» (Sirenum uoces et Circae pocula, v. 23) como amenazantes seducciones que el prudente Ulises fue capaz de vencer. La diosa de Eea y las criaturas cantoras representan la lujuria, el poder de las meretrices (domina meretrice, v. 25), que degrada al hombre al nivel de la bestia, «como un perro inmundo o un cerdo propicio al fango» (canis inmundus uel amica luto sus, v. 26). En Sat. II, 3 14-15 compara Horacio a las sirenas con otra tentación: la pereza ${ }^{21}$.

18 Una excepción es $\Gamma \rho \cup ́ \lambda \lambda o \varsigma$ o Bruta animalia ratione uti de Plutarco, que enfrenta a un Odiseo necio y a una Circe sabia. Grilo, uno de sus cerdos, muestra al héroe que la vida animal es la más feliz. El espíritu de este diálogo filosófico, con parodia, desmitificación y filosofía cínica, está próximo del microcuento. Inspiró en el Humanismo obras como L'Asino (Maquiavelo), La Circe (Gelli), El Crótalon (Villalón) y Les compagnons d'Ulysse (La Fontaine).

19 El neotérico Levio había fusionado los episodios de Circe y las sirenas en la obra perdida de temática erótica Sirenocirca. La corriente de la Circe enamorada desemboca en recreaciones como La Circe de Lope de Vega.

20 Según Hyg., Fab. CXLI, Ceres las castigó con la forma de ave por no ayudar a su hija cuando fue raptada.

21 Ya Platón usó los cantos de las sirenas como símbolo de la seducción (Smp. 216a), y Jenofonte las metamorfosis de Circe para ilustrar las consecuencias del desenfreno (Mem. I 3,7). En el s. IX León el Filósofo aúna ambos temas con la misma orientación moral que Horacio en el epigrama $A P$. XV 12. 
Este enfoque es el predominante en la exégesis alegórica de mitos, que leyó los relatos tradicionales desde postulados estoicos, platónicos o evemeristas, y cuyo relevo será asumido por los cristianos. Los exegetas tienden a ver a Circe y a las sirenas como figuraciones simbólicas de la pasión nociva, los vicios y los impulsos irracionales que se pueden combatir con templanza y autocontrol ${ }^{22}$. Comienza un proceso de erotización de estas figuras que acabará imponiéndose en la tradición literaria. Esta evolución se refleja en la iconografía. Durante la Antigüedad la imagen canónica de la sirena es una mezcla de mujer y ave, como la describen los textos. A partir de los siglos IV-V d.C. comienza su representación más sensual como mujer con cola de pez, y esta apariencia prevalece desde los bestiarios medievales ${ }^{23}$.

La visión moralista de las aventuras de Circe y las sirenas como símbolos de la seducción y el engaño triunfará en el Medievo y en los manuales mitográficos del Renacimiento. En algunos de estos tratamientos las figuras de Circe y las sirenas aparecen mezcladas y equiparadas ${ }^{24}$.

En el tránsito de la Edad Media al Renacimiento están las alusiones a la Odisea de la Divina Comedia, escuetas pero de inmenso eco en las letras occidentales. En Infierno XXVI 90-142 un Ulises audaz y transgresor relata su insensata navegación desde la isla de Circe hasta el fin del mundo, donde su nave es engullida por un torbellino. Dante parte de la visión positiva de Odiseo como héroe astuto y curioso ${ }^{25}$, y la extrema hasta mostrar a un viajero guiado por la osadía y el ansia de acumular experiencias a cualquier precio. Sobre este vehemente Ulises dantesco —que habría corrido al encuentro de aquellas sirenas homéricas que ofrecían el saber- se va a construir la imagen moderna del héroe. En Purgatorio XIX 19-24 aparece una misteriosa fémina que se transforma desde la deformidad hasta la hermosura y entona un irresistible canto. Esta figura parece construida sobre la fusión de los personajes de las sirenas y Circe $^{26}$.

Un hito en la tradición de Circe y las sirenas en la literatura hispana es la Oda IX (Las Serenas. A Cherinto) de Fray Luis de León, primer tratamiento artístico del tema en nuestras letras. El poema trata sobre los peligros que acechan al alma - en particular la lujuria-, encarnados por Circe y las sirenas. Ulises es el ejemplo a seguir («imita al alto griego», v. 36), el varón virtuoso y comedido, y sus hombres los

22 Practican la alegoría de Homero en esta línea otros autores como Heráclito el Alegorista, Pseudo-Plutarco, Heráclito Paradoxographus, Porfirio, Lactancio Plácido, Ambrosio, Paulino de Nola, Fulgencio, etc. Para el tema de la exégesis de mitos son fundamentales los estudios de Pépin (1976) y Rahner (2003).

23 Sobre la iconografía de las sirenas, véase Hofstetter, Krauskopf (1997: 1093-1104).

24 Clem. Al., Prot. XII 118, 2 describe una isla cubierta de huesos humanos donde canta una lasciva cortesana. Según Phys. XV la naturaleza mixta de las sirenas es un reflejo de su alma doble y falsa, probablemente considerando los halagos y ofrecimientos que dirigen a Odiseo en Od. XII 184-192. También Circe es «engañosa» desde

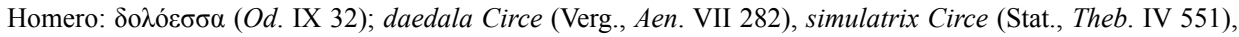
versipellis Circae (Arnob., Nat. IV, 14)... Para Boecio las metamorfosis de Circe simbolizan la animalización por los vicios (IV metrum III) y las sirenas son «dulces para la destrucción» (in exitium dulces, I.1.11). En San Isidoro las sirenas son prostitutas y Circe una maga maligna (Etym. XI 3, 30-31 y XVIII, 28, 2). Hacen lecturas similares Boccaccio, Conti, Pérez de Moya...

25 Eran célebres los elogios de Horacio a la sabiduría de Ulises: Ep. I 2, 17-22 (quid uirtus et quid sapientia possit, utile proposuit nobis exemplar Vlixen) y Ep. II 3, 141-142 (Qui mores hominum multorum vidit et urbes).

26 «Yo soy — cantaba - la dulce sirena, / que en la mar enloquece a los marinos; tan grande es el placer que da el oírme. / Yo aparté a Ulises de su incierta ruta/con mi cantar; y quien se me habitúa, / raramente me deja: ¡Así lo atraigo!». 
pecadores que se pierden. Tal interpretación coincide con las exégesis grecolatinas que fueron asumidas por los cristianos: ${ }^{27}$. El poema evoca la bebida apetitosa y funesta con la que Circe hechiza (vv. 1-5), la belleza física que envenena el espíritu (vv. 6-10), el prado «mortal, aunque florido» con letales serpientes (vv. 11-12) ${ }^{28}$, las metamorfosis en fieras (vv. 21-30), la resistencia de Ulises al canto de las sirenas (vv. 36-65) $)^{29}$.

A partir del Renacimiento y el Barroco la mitología clásica impregna todas las creaciones artísticas. Los mitos de Circe y las sirenas se encuentran entre los preferidos, siempre tratados desde la óptica edificante cristiana ${ }^{30}$. La sirena pisciforme se va equiparando a las bellas ninfas acuáticas, proceso que se aprecia del todo cumplido en el Romanticismo, con sirenas seductoras, a veces dulces y a veces temibles (así en La Sirenita de Andersen, los cuentos «La Sirena del Rin» de Dumas, «Los Ojos Verdes» de Bécquer, etc.).

A partir de la Modernidad podemos hablar de una serie de eslabones que, si no han sido fuente de inspiración directa para nuestros microrrelatos, están impregnados del mismo espíritu artístico e ideológico. Las recreaciones por norma general están marcadas por la desmitificación y la perversión de lo heroico y mitológico, pero suelen mantener en esencia la visión heredada de Circe y las sirenas: hay una línea de continuidad en las reelaboraciones de los exegetas antiguos, los cristianos y los literatos modernos.

Los decadentistas manifestaron su atracción por Circe y las sirenas como tipos femeninos seductores y destructivos. Poemas como «Á la Circé moderne» (Les Névroses, 1883) y «Le chat blanc» (Les bêtes, 1911) de Maurice Rollinat, «L'incanto Circeo» (Alcyone III 1903) de D'Annunzio, o «Les sirènes» y «Lul de Faltenin» (Alcools, 1913) de Apollinaire son sólo una muestra de tratamientos de esta índole. Pero el gran hito en la recepción moderna de la Odisea es el Ulysses (1922) de Joyce - para muchos incluso el primer exponente de la escritura posmoderna-, donde las sirenas y Circe se encarnan respectivamente en las camareras del Episodio $11 \mathrm{y}$ la prostituta del Episodio 15 de la Parte II. También en 1922 comienza Pound, otro de los grandes exponentes de la corriente modernista, a publicar sus Cantos, donde las alusiones a la cultura clásica son constantes. Circe aparece aquí (en especial en los Cantos I y XXXIX) como una mujer lasciva que tienta a un Odiseo errante, atormentado y débil.

Influirán también en los tratamientos homéricos de los microcuentos las visiones posmodernas donde los mitos clásicos se humanizan y se toman como alegoría de los sucesos y las pasiones vitales. Un ejemplo son los Dialoghi con Leucò (1947) de Pavese: en «Le streghe» presenta a una Circe sensible y enamorada de un Odiseo indiferente, egoísta y embrutecido.

27 Los modelos de Fray Luis serían Horacio y Dante. Es muy similar el poema de Ronsard «Le chant des serenes», que aconseja a Jamin seguir el ejemplo de Ulises y evitar a las sirenas; la datación de la Oda IX es insegura, pero puede ser anterior al texto francés. Sobre el mismo tema escribe Juan de Arquijo su Soneto XXXI.

28 La reminiscencia homérica ( $\lambda \varepsilon \mu \mu \tilde{\omega} v^{\prime} \dot{\alpha} v \theta \varepsilon \mu$ ó $\varepsilon \tau \tau \alpha, O d$. XII 158-159) se enriquece con el motivo de los peligros del Edén.

29 Los vv. 42-60 reproducen fielmente el discurso que pronuncian las sirenas en Od. XII 184-194.

30 Calderón les dedica varias piezas: Polifemo y Circe (1630), El mayor encanto, amor (1635), Los encantos de la Culpa (1645) y El golfo de las sirenas (1657). Lope había compuesto La Circe basándose en Od. X y en Aen. IV. 
Las tendencias literarias de la Modernidad se dejan sentir simultáneamente en Europa y América ${ }^{31}$. En el género narrativo mayor, la novela, hay dos grandes recreaciones hispanoamericanas de la Odisea en la línea de Joyce: Adán Buenosayres (1948) de Marechal y Rayuela (1963) de Cortázar. Cortázar y Borges, figuras sobresalientes en la renovación de las letras de este continente, afectan de manera particular al tipo de narrativa que nos ocupa, pues cultivan el cuento y emprenden la recreación de los mitos clásicos. El primero compone un cuento formidable y atroz, «Circe» (llevado al cine en 1964 por Manuel Antín) donde la diosa se transfigura en Delia Mañara, una misteriosa muchacha que entabla inquietantes relaciones con sus novios y con los animales. La condición monstruosa de esta moderna Circe viene subrayada por el hecho de que el relato forme parte de una obra titulada Bestiario (1951). En otro bestiario, Borges hace una aportación erudita y exegética más que literaria, al tema de las sirenas. Las devuelve al molde libresco que tradicionalmente se había ocupado de ellas al dedicarles un capítulo de El libro de los seres imaginarios (originalmente Manual de zoología fantástica, en 1957, escrito en colaboración con Margarita Guerrero ${ }^{32}$ ). Es sólo una de las muchas referencias homéricas de la obra de Borges: tal vez el poema «Odisea, libro vigésimo tercero» es de sus textos el más próximo en su espíritu a los microcuentos sobre Circe y las sirenas ${ }^{33}$.

\section{EI microrrelato y la intertextualidad}

Sin pretender llevar a cabo un análisis de la naturaleza y la historia del microrrelato, parece conveniente, antes de estudiar los microcuentos de inspiración odiseica, detenernos en algunos de sus aspectos generales y particularmente en los que atañen a sus mecanismos intertextuales.

Desde tiempos remotos se documentan esquemas literarios que se definen por la brevedad, el ingenio y la autonomía: fábulas, cuentos, epigramas, aforismos, sententiae, parábolas, bestiarios, exempla.... Pero el germen de la microficción está en la renovación modernista que tan fecunda resultó en Hispanoamérica y que abrió las puertas a la innovación y el sincretismo estético: todas las fuentes son asumidas y transformadas. Los antecedentes directos de la ficción mínima son los poemas en prosa modernistas como Le Spleen de Paris o Petits poèmes en prose de Baudelaire y piezas de $A z u l \ldots$ de Daríi ${ }^{34}$, los versos libres y la prosa poemática de Juan Ramón Jiménez, las Greguerías (1917) de Gómez de la Serna, que se anticipan al movimiento surrealista y los textos fragmentarios y sintéticos de las vanguardias.

31 Pellicer (1998: 129-133) repasa el tema de las sirenas en Hispanoamérica en el tránsito del XIX al XX.

32 Este libro alude al $\mu \tilde{\omega} \lambda v$ del episodio de Circe en el capítulo sobre la mandrágora. El apartado sobre Escila narra su transformación en monstruo marino por obra de Circe según Ov. Met. XIII 898- XIV 74.

33 Otra obra afín al bestiario que puede haber inspirado a los microcuentistas es Ocaso de Sirenas. Manaties en el siglo XVI (1950) del peruano José Durand, que recoge textos breves de conquistadores españoles sobre una extraña criatura marina, similar a la sirena, que habían descubierto en América: el manatí. Por otra parte, un cuento del mexicano René Avilés, «El banquete de Ulises» (Fantasías en carrusel, 1969-1994), aunque menos conocido, merece ser reseñado. Plagado de citas textuales de $O d$. X, reconstruye la aventura de Eea con la intención declarada de contar la verdad. Ulises se entrega al disfrute con Circe y olvida rescatar a sus compañeros hechizados; al marcharse comprende que se los ha comido en los banquetes de Circe, cumpliéndose así la ominosa amenaza que estaba latente en la Odisea.

34 Algunos reivindican como los primeros minicuentos textos breves de Darío previos a Azul... que vieron la luz en revistas, como «La resurrección de la rosa» (1892) o «El nacimiento de la col» (1893). 
El cuento literario se va abreviando desde finales del XIX, y durante los años veinte y treinta del siglo xx se produce en Hispanoamérica el tránsito del cuento breve a la minificción, con Ensayos y poemas (1917) de Torri como obra pionera ${ }^{35}$. Grandes figuras del cuento americano lo cultivan también en su forma hiperbreve: entran en esta categoría los «casos» de Anderson Imbert (El Grimorio, 1961; El gato de Cheshire, 1965...), los «textículos» de Cortázar (La vuelta al día en ochenta mundos, 1967; Último round, 1969) y los textos mínimos repartidos por la obra de Borges («Los dos reyes y los dos laberintos», «Le Regret d'Héraclite»...) ${ }^{36}$. El microcuento se configura definitivamente hacia los años 60 , aunque no hay acuerdo en si se trata de un género, una submodalidad del cuento, un producto del cruce de géneros... Dentro de su variedad temática y formal, la pauta general es la de un relato ficcional, con hibridismo o difuminación del género, indistintamente fantástico o realista -a menudo con un realismo que aplasta el elemento maravilloso tradicional-, con personajes tipo o figuras de la tradición, humor irónico y paródico, comienzo in medias res, fragmentarismo, final abrupto o abierto, y estilo elegante y sugerente.

En el microcuento juega un papel preponderante la metaliteratura, siendo las fuentes primordiales aquéllas que sustentan el acervo cultural de Occidente: la cultura clásica ${ }^{37}$, la Biblia, obras maestras de la literatura, cuentos populares, fábulas, etc. La referencia a hitos de la tradición permite la evocación elíptica de historias célebres y la interactuación con un lector activo, que comparte con el autor todo un universo literario y es capaz de completar las omisiones con su bagaje cultural previo. Veremos piezas donde la intertextualidad incluso ocupa todo el espacio, y la inferencia intertextual es indispensable. («El hombre, animal lujurioso» de Denevi, «Silencio de Alcoba» de Perucho, etc.).

A la hora de reelaborar el legado grecolatino, Homero es la fuente preferida en los microrrelatos, especialmente la epopeya de Odiseo, quizá la obra que más reelaboraciones, alusiones y comentarios ha generado entre los escritores europeos y americanos $^{38}$. La parte preferida para la reescritura ha sido siempre la más novelesca - Cantos IX-XII-, donde se enmarcan las aventuras fantásticas: los Cíclopes, Circe, las sirenas, la invocación al Hades... Los episodios de Circe y las sirenas ocupan un puesto primordial en la minificción desde «A Circe» de Julio Torri (1917), el primero de los textos que vamos a estudiar.

Será útil examinar nuestros microrrelatos atendiendo los tipos de relaciones transtextuales que señaló Genette: intertextualidad, entendida como citas o alusiones de un texto en otro; relación de un texto con su paratexto; metatextualidad o elaboración de un texto como comentario de otro; architextualidad o mecanismos de clasificación genérica; y por último hipertextualidad, la dependencia de un hipotexto sobre el cual el hipertexto puede realizar transformaciones simples o complejas ${ }^{39}$. Todas estas formas de transtextualidad se innovan con gran virtuosismo en la

35 Otros precursores del microrrelato son Ramón López Velarde (El minutero, 1923), Leopoldo Lugones (Filosoficula, 1924), Alfonso Reyes (Calendario, 1924), Macedonio Fernández (Papeles de Recienvenido, 1929), etc.

36 El microrrelato ha sido proclive a presentarse en colecciones. A Borges y Bioy Casares debemos la primera, Cuentos breves y extraordinarios (1955), que recogía textos de distinta procedencia (antiguos, modernos, propios...).

37 Serrano Cueto (2015) ha editado recientemente una antología de microrrelatos de tema clásico.

38 En palabras de Genette (1989: 222), la Odisea es «el blanco favorito de la escritura hipertextual».

39 Genette (1989: 10-20). 
literatura moderna, pero se habían practicando desde la Antigüedad, y precisamente aplicadas muy a menudo a Homero, el gran modelo literario. El caso del microrrelato ilustra bien los mecanismos de la recepción transtextual posmoderna.

Resulta igualmente apropiada para nuestro tema la clasificación que hace García Gual de los usos literarios del mito: alusión, amplificación novelesca, prolongación, ironía y reinterpretación subversiva ${ }^{40}$. Los tres últimos mecanismos - la adición de sucesos que no figuraban en el mito, el distanciamiento humorístico y la lectura ideológica ajena al relato primigenio-, actúan, casi siempre mezclados, en el microcuento.

Una última tipología que puede orientarnos son las cinco modalidades básicas de microrrelato que propone Lagmanovich: ciertas minificciones son reescrituras o parodias de creaciones clásicas; otras recurren a un discurso sustituido, para experimentar con el lenguaje y alterar sus normas; algunas, mediante escritura emblemática, ofrecen reflexiones trascendentes de la existencia; constituirían otra clase las creaciones protagonizadas por animales, que recuperan y modernizan la tradición de la fábula y el bestiario; para finalizar, ciertas piezas se articulan como un discurso mimético para recrear el habla cotidiana ${ }^{41}$. La mayoría de textos que recogemos presentan reescritura y parodia de la Odisea; además, algunos están próximos a la modalidad del bestiario y otros complementan la recreación con una lectura emblemática.

\section{Microrrelatos sobre Circe y las sirenas}

No pretendemos hacer un recuento completo de microcuentos inspirados en Circe y las sirenas, sino esbozar un panorama general. Para nuestra selección nos hemos guiado sobre todo por los criterios de la transtextualidad con modelos clásicos y modernos y de la representatividad de tendencias generales del tratamiento del mito en el relato hiperbreve. La disposición se estructura en tres grandes bloques temáticos: versiones derivadas del primer tratamiento, el de Torri, textos basados en la figura de Circe y textos basados en los personajes de las sirenas. Organizamos cada sección por orden cronológico y, dada la escasa extensión de las composiciones, las recogemos completas para mayor comodidad.

\subsection{Sirenas silenciosas: variaciones de Torri}

Comenzamos nuestro recorrido con «A Circe» del mexicano Julio Torri, la pieza más significativa por varios motivos: tradicionalmente se ha tenido a Torri como el iniciador del microrrelato y «A Circe» como el primer ejemplo de este nuevo arquetipo literario ${ }^{42}$; en segundo lugar, el texto de Torri inaugura la fecunda tradición de microrrelatos sobre Circe y las sirenas.

\footnotetext{
García Gual (1999: 186-194).

Lagmanovich (2006: 127-138).

42 Todo el corpus de Torri se define por la concisión, el hibridismo genérico, el ingenio y la intertextualidad, y existen textos previos suyos con estas características: ya en 1905 publica en La Revista la minificción «Werther». «A Circe»se interpretó en su día como un poema y se incluyó en Antología de poetas modernos de México (1920); Lagmanovich (2006: 106) demuestra sus difusos límites genéricos al disponer esta pieza en versos.
} 
¡Circe, diosa venerable! He seguido puntualmente tus avisos. Mas no me hice amarrar al mástil cuando divisamos la isla de las sirenas, porque iba resuelto a perderme. En medio del mar silencioso estaba la pradera fatal. Parecía un cargamento de violetas errante por las aguas.

¡Circe, noble diosa de los hermosos cabellos! Mi destino es cruel. Como iba resuelto a perderme, las sirenas no cantaron para mí. «A Circe» (Ensayos y poemas, 1917)

Torri se inspira en la visita a la isla de las sirenas y la profecía previa de Circe de $O d$. XII y se mantiene cercano al hipotexto: Odiseo afronta los peligros de la navegación amparado por los consejos de Circe, que no se define aquí por la seducción ni la magia, sus atributos más repetidos por la tradición, sino por su papel de profetisa y guía, casi olvidado desde la Odisea. El discurso en estilo directo, pese a la pátina de lirismo, emula la dicción de la épica arcaica, con oraciones breves, símiles, epítetos y apóstrofes que reproducen las fórmulas homéricas («diosa

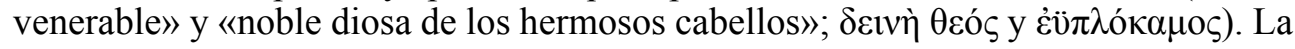
alusión a la «pradera fatal» semejante a «un cargamento de violetas errante» remite al «prado florido» de $O d$. XII 159 y de la Oda IX de Fray Luis (vv. 11-12).

Un anónimo protagonista que tenemos que identificar con Odiseo relata a Circe su aventura con las sirenas, situación que no encaja en la Odisea. El personaje de Torri sale indemne del encuentro con esas criaturas, pero tal desenlace se produce y se percibe al revés que en la epopeya: para este nuevo Odiseo es un drama no haberse detenido en su isla. Si el héroe épico navegó hacia las sirenas lleno de cautela y advertencias de Circe, el de Torri es su antítesis, un antihéroe «resuelto a perderse». Acorde con la concepción dantesca de un Ulises temerario y arriesgado, se entrega deliberadamente a su ruina, pero fracasa en su intento de fracasar y no logra consumarla.

La diosa de Eea, convertida en una especie de consejera, escucha su amarga confesión a través de lo que podría ser un diálogo pero queda en un monólogo al no figurar respuesta de Circe, quizá porque estamos ante un soliloquio o un monólogo interior. En cualquier caso, la alocución a la diosa mantiene el tono de distancia y respeto que empleaba el héroe homérico al dirigirse a ella. El «yo» narrativo afirma lacónicamente haber seguido los consejos de Circe, y podemos suponer que ha sido en otras aventuras ${ }^{43}$; en el caso de las sirenas se ha apartado de las instrucciones de Circe. Ya la Circe homérica había previsto que Odiseo no se resistiría a escuchar el canto de las sirenas (Od. XII 49-52), y por ello le recomendó hacerlo atado al mástil, pero el Odiseo de Torri no se conforma con escucharlas: quería dejarse arrastrar a su isla.

De acuerdo con la interpretación común del mito homérico, las sirenas se identifican con la tentación. El enfoque de Torri coincide con las exégesis moralistas, aunque su espíritu cuenta con un modelo más inmediato: los movimientos finiseculares. $\mathrm{Su}$ actualización de $O d$. XII se asocia a ese tema tan del gusto del Decadentismo de la atracción por el abismo, la búsqueda de la propia perdición. Varios críticos creen que Torri funde aquí lo mítico y lo autobiográfico ${ }^{44}$ para expresar su frustración personal. Lo que está claro es que, junto a la parodia y el humor amargo, el relato homérico

43 En la Odisea las profecías de la diosa se orientan a la véкvı, las sirenas, el paso entre Escila y Caribdis y la isla de Trinaquia, y sólo en los dos primeros casos eran seguidas al pie de la letra.

44 Para Pollastri (2012: 1657) la primera persona funde narrador, autor y personaje. También habla de autobiografismo Zaïtzeff (2004: 294), y considera que Torri en pocas líneas «reduce a su esencia el tema de lo que podría haber sido novela; la tragedia de un hombre determinado que fracasa en un mundo que no puede controlar». 
sirve para representar una serie de ideas atemporales como son el choque entre lo racional y lo concupiscible, la atracción morbosa por la tentación, la angustia del deseo insatisfecho... «A Circe», por tanto, establece con la Odisea una relación hipertextual que incluye la reescritura irónica de Homero y su tradición y la función emblemática del mito.

El tema de un Ulises que no consigue consumar la tentación de las sirenas aparecerá a menudo por imitación de Torri en el microrrelato hispanoamericano. Es interesante aludir a tres textos de autores occidentales de primer orden que ofrecen variaciones similares sobre el tema mítico de la seducción del canto.

Un enfoque coincidente con el de Torri aparece en el poema «The Love song of Alfred Prufrock» de Eliot, publicado en 1915, en la revista A Magazine of Verse y en 1917 en el libro Prufrock and Other Observations. En los versos 124-125 leemos «I have heard the mermaids singing, each to each. / I do not think that they will sing to me» («He oído a las sirenas cantándose unas a otras./ No creo que me canten a mí»).

En el cuento «Das Schweigen der Sirenen» («El silencio de las sirenas») —escrito por Kafka en 1919 pero publicado en 1931 - se comenta que Ulises se protegió doblemente contra las sirenas atándose al mástil y tapando sus oídos. Pero el narrador afirma que no hay precaución posible contra el canto omnipotente de las sirenas. El desenlace es chocante: las sirenas, viendo los vanos esfuerzos de aquel infeliz, por desprecio o por lástima decidieron no cantar. Se describen con condescendencia las estratagemas de Ulises y en ningún momento se atribuyen a Circe, ignorada en este relato (igual que los compañeros). Pero no se niega del todo la proverbial astucia del héroe: atendiendo a su fama de mentiroso, la voz narrativa sugiere que quizá él se dio cuenta de lo que ocurrió, pero ocultó a todos, hasta a los dioses, su humillación.

Brecht se basa en esta idea de Kafka y la lleva más allá en «Odysseus und die Sirenen» («Odiseo y las sirenas», 1933), otro cuento en forma de explicación del episodio de la Odisea. Supone el narrador que Ulises quiso disfrutar del canto de las sirenas, y por eso se hizo atar al mástil pero tapó los oídos de los remeros; la hipótesis en este caso sí se corresponde con $O d$. XII 47-52. Al pasar frente a las sirenas, el héroe se agita, como en Homero, y sus remeros creen que lucha contra la atracción del canto. Pero la realidad sería que las sirenas, viéndolo atado, renunciaron a cantar en vano y en vez de eso lo insultaron. Odiseo pierde su heroicidad para convertirse en un «condenado y cauto provinciano» ${ }^{45}$.

Dada la cercanía de las fechas de publicación, es difícil que Torri se inspirara en los versos de Eliot; respecto a los cuentos de Kafka y Brecht, son posteriores al de Torri. Debemos concluir que en las primeras décadas del siglo xx el motivo de las sirenas que no cantan se estaría usando como tópico para reflejar la desilusión, la represión del deseo y el no cumplimiento de las expectativas, temas muy del gusto de la Modernidad.

La composición de Torri abre el camino a los relatos ultracortos de inspiración odiseica. Marco Denevi es un autor fundamental en el desarrollo del microrrelato,

45 Para una visión comparada de los tratamientos de Kafka y Brecht, cf. Conchillo \& Sánchez (1988: 50-61). 
que cultiva desde los inicios del género hasta los años $90^{46}$. Denevi pasa el mito por el filtro de la actualización, el humor y la revisión desde un punto de vista femenino. $\mathrm{Su}$ reescritura paródica de $\mathrm{Od}$. XII entronca con las de Torri, Kafka y Brecht:

Cuando las Sirenas vieron pasar el barco de Ulises y advirtieron que aquellos hombres se habían tapado las orejas para no oírlas cantar (¡a ellas, las mujeres más hermosas y seductoras!) sonrieron desdeñosamente y se dijeron: ¿Qué clase de hombres son estos que se resisten voluntariamente a las Sirenas? Permanecieron, pues, calladas, y los dejaron ir en medio de un silencio que era el peor de los insultos. «Silencio de Sirenas» (Falsificaciones, 1966)

En vez de focalizar la atención en Ulises, Denevi la amplía a todos los remeros. Al parecer, todos los navegantes se han tapado los oídos, incluido el caudillo: este detalle, así como la estrecha semejanza del título, apunta a «El silencio de las sirenas» de Kafka. El autor checo planteaba que las sirenas podían haber callado como forma de manifestar su desdén ante las precauciones de Ulises, un silencio que, como comenta Denevi, habría sido «el peor de los insultos», más doloroso tal vez que las injurias de las sirenas de Brecht. Así, estas criaturas, que no son temibles, sino «hermosas y seductoras», castigan la necedad de los navegantes. Frente al uso de la primera persona en el texto de Torri y a la forma de glosa en los de Kafka y Brecht, Denevi vuelve al narrador omnisciente en tercera persona que figuraba en Homero.

También en La oveja negra y demás fábulas, singular y chispeante libro de minificciones-fábulas de Augusto Monterroso, las sirenas callan al paso de Ulises:

Usó todas sus voces, todos sus registros; en cierta forma se extralimitó; quedó afónica quién sabe por cuánto tiempo.

Las otras pronto se dieron cuenta de que era poco lo que podían hacer, de que el aburridor y astuto Ulises había empleado una vez más su ingenio, y con cierto alivio se resignaron a dejarlo pasar.

Ésta no; ésta luchó hasta el fin, incluso después de que aquel hombre tan amado y deseado desapareció definitivamente.

Pero el tiempo es terco y pasa y todo vuelve.

Al regreso del héroe, cuando sus compañeras, aleccionadas por la experiencia, ni siquiera tratan de repetir sus vanas insinuaciones, sumisa, con la voz apagada, y persuadida de la inutilidad de su intento, sigue cantando.

Por su parte, más seguro de sí mismo, como quien había viajado tanto, esta vez Ulises se detuvo, desembarcó, le estrechó la mano, escuchó el canto solitario durante un tiempo según él más o menos discreto, y cuando lo consideró oportuno la poseyó ingeniosamente; poco después, de acuerdo con su costumbre, huyó.

De esta unión nació el fabuloso Hygrós, o sea «el Húmedo» en nuestro seco

46 Dos de los tres textos que hemos escogido pertenecen a Falsificaciones (1966, aumentado en 1984), que recoge originales relecturas de la literatura, la historia o el mito. El título alude a la intertextualidad como motor creador, a la ficción y a la verdad múltiple: «Falsificaciones cuestiona la versión única de la escritura, pone en juego sus múltiples posibilidades; la verdad única se diluye en un mar de otras formas proteicas» (Flawiá de Fernández \& Assis de Rojo 2008: 145). 
español, posteriormente proclamado patrón de las vírgenes solitarias, las pálidas prostitutas que las compañías navieras contratan para entretener a los pasajeros tímidos que en las noches deambulan por las cubiertas de sus vastos trasatlánticos, los pobres, los ricos, y otras causas perdidas.

«La sirena inconforme» (La oveja negra y demás fábulas, 1969)

Como en «Silencio de sirenas» de Denevi, el hipotexto de base es Od. XII, pero los más próximos son los de Torri, fundador del microrrelato, y Kafka, a quien Monterroso dirige frecuentes guiños y homenajes. Estas sirenas callan, igual que las del escritor checo, cuando comprenden que Ulises emplea una artimaña -aquí no especificada por sabida - para escapar a su hechizo. Al motivo de las sirenas silenciosas añade Monterroso una innovación: hay una sirena individualizada que insiste en cantar hasta la extenuación: se esfuerza por detener la marcha del héroe, como Calipso en $O d$. V y Dido en Aen. IV, y fracasa como aquéllas. El hipertexto guatemalteco incorpora una prolongación de la aventura: el cínico y sagaz Ulises regresa junto a esta sirena y yace con ella, para después abandonarla. Ampliando su remedo también a la tradición mitográfica, concluye Monterroso con una simulada explicación etiológica: esta sirena dio a luz a un hijo llamado Hygrós (efectivamente,

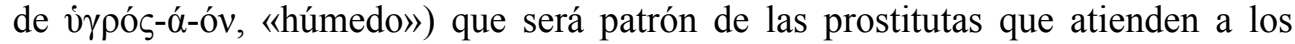
marineros ${ }^{47}$.

El siguiente microcuento de Enrique Anderson Imbert es el único en el cual es Jasón y no Odiseo quien vive la experiencia de las sirenas que no cantan.

Odiseo fue el primero en contarlo, pero la verdad es que, antes de conocer a Odiseo, ya Circe había avisado a Jasón que tuviese cuidado al pasar por la isla de las sirenas: con sus cantos lo harían arrojarse al mar, a menos — le dijo- que se tapara con cera los oídos u ordenase a los argonautas que lo ataran al mástil. Jasón no quiso cuidarse. Las sirenas, al verlo tan jactancioso, no le cantaron, y así, cruelmente, lo dejaron sin nada que decir.

«Jasón» (La sandía y otros cuentos, 1969)

En un texto que adopta, como muchos de los que estamos viendo, la forma de comentario, el escritor argentino demuestra su conocimiento de la mitología griega, donde cronológicamente Jasón era el primer héroe famoso que se enfrentó a las sirenas. Según la tradición más autorizada — presente en A.R. IV 885-921 y otras fuentes antiguas - , escapó de las sirenas gracias al canto mágico de Orfeo, ignorado aquí. Anderson Imbert inventa que Circe, de nuevo guía y profetisa, habría dado a Jasón las mismas instrucciones que dirigió a Odiseo en Homero. El líder de la nave Argo muestra en este texto la misma osadía que el Odiseo de Torri, y las sirenas el mismo orgullo ofendido que las del cuento de Kafka. Este incidente le sirve para justificar por qué el encuentro de Jasón con las sirenas no habría obtenido el mismo

47 Es un desarrollo del mito imaginativo e insólito; algunas fuentes hablaban de descendencia de Odiseo nacida de Circe y Calipso (Telégono, Latino...), pero nunca de las sirenas. La oveja negra y demás fábulas contiene otro famoso microrrelato con forma de metatexto de la Odisea: «La tela de Penélope o quién engaña a quién» explica la verdad sobre la espera de la fiel Penélope, con el fin de enmendar la versión de Homero «que, como se sabe, a veces dormía y no se daba cuenta de nada». 
prestigio que el de Odiseo: la gloria épica se cifra en el enfrentamiento con las sirenas: no haberlo tenido supone el oscurecimiento de la fama.

«Aviso» del mexicano Salvador Elizondo se plantea desde la dedicatoria como un homenaje a Torri y una respuesta al microrrelato de aquel. Como en «A Circe», un narrador en primera persona - de nuevo un Odiseo de inspiración dantescaconfiesa que desoyó los «prudentes consejos» de Circe y se lanzó a la tentación de las sirenas.

\section{M. Julio Torri}

La isla prodigiosa surgió en el horizonte como una crátera ${ }^{48}$ colmada de lirios y de rosas. Hacia el mediodía comencé a escuchar las notas inquietantes de aquel canto mágico.

Había desoído los prudentes consejos de la diosa y deseaba con toda mi alma descender allí. No sellé con panal los laberintos de mis orejas ni dejé que mis esforzados compañeros me amarraran al mástil.

Hice virar hacia la isla y pronto pude distinguir sus voces con toda claridad. No decían nada; solamente cantaban. Sus cuerpos relucientes se nos mostraban como una presa magnífica.

Entonces decidí saltar sobre la borda y nadar hasta la playa.

Y yo, oh dioses, que he bajado a las cavernas de Hades y que he cruzado el campo de asfódelos dos veces, me vi deparado a este destino de un viaje lleno de peligros. Cuando desperté en brazos de aquellos seres que el deseo había hecho aparecer tantas veces de este lado de mis párpados durante las largas vigías del asedio, era presa del más agudo espanto. Lancé un grito afilado como una jabalina.

Oh dioses, yo que iba dispuesto a naufragar en un jardín de delicias, cambié libertad y patria por el prestigio de la isla infame y legendaria.

Sabedlo, navegantes: el canto de las sirenas es estúpido y monótono, su conversación aburrida e incesante; sus cuerpos están cubiertos de escamas, erizados de algas y sargazo. Su carne huele a pescado.

$$
\text { «Aviso» (El grafógrafo, 1972) }
$$

La reescritura de Elizondo explota un estilo marcadamente poético, plagado de epítetos sugerentes y expresiones de inspiración homérica: los «esforzados compañeros», el «campo de asfódelos», las «cavernas del Hades», la isla comparada con «una crátera colmada de lirios y de rosas» ${ }^{49}$. Circe sólo es nombrada como «la diosa», y los vocativos que en la pieza de Torri estaban destinados a ella se dirigen aquí a los dioses y finalmente a los navegantes, auténticos destinatarios del aviso. Esa voz narrativa de Odiseo parece arrogarse poderes propios de Circe y de Tiresias para informar a los viajeros ignorantes de lo que les aguarda. Ese aviso sobreviene en el último párrafo, donde la gravedad y el lirismo que dominan todo el texto se interrumpen para formular la transformación paródica del hipotexto homérico: si el

48 «Crátera» ( $\mathrm{sic}$ ) en todas las ediciones que recogen este texto, aunque la forma correctamente acentuada es «cratera».

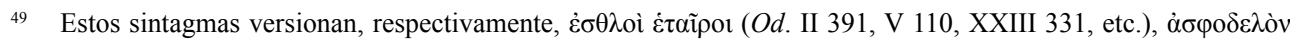

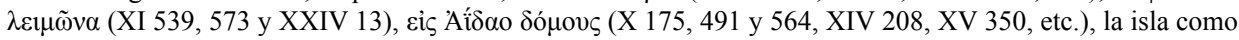

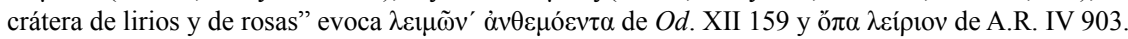


protagonista de Torri no puede consumar su transgresión porque las sirenas no le cantan, el de Elizondo llega hasta ellas pero queda hondamente desengañado: son charlatanas y aburridas, con cuerpo de pez rugoso y hediondo, una cruda descripción que remite a la tradición de los bestiarios. El motivo de la frustración de las ansias planteado en Torri es sustituido por el de la decepción al satisfacerlas.

Otro mexicano, Marco Antonio Campos, reelabora el modelo de Torri sin alterar en este caso el desenlace:

Cuando llegué a la isla creí que las sirenas me esperaban desde siempre. Yo, que huía de mí, de una mujer, de los días de fracaso que caían en mi sangre como la luna en el mar, buscaba perderme en la espesura de su canto. ¿La causa? - preguntarán-. Fue desde aquella mañana de invierno cuando supe que el amor era un engaño de la sangre; cuando supe que la ternura o la piedad eran dos fieras inútiles en las selvas del hombre. Por eso quise perderme; por eso quise escuchar su canto, que aun siendo el más dulce, el más hondo, será para mí, de todos modos, un pretexto más para la tristeza. Yo quiero oírlo, ya...

Estoy cruelmente satisfecho. Me doy cuenta que incluso en la destrucción se puede hallar la felicidad. Sonrío al recordar el pasado, aunque en esa sonrisa —no hay remedio - haya el signo de la derrota. Pero qué importa, ¡bah!, me muero de tristeza y rencor.

Miro el atardecer: los dientes blanquísimos de las olas, las nubes que empiezan a calcinar con sus dedos las ramas del horizonte. ¿Las voces? ¿Las voces? ¡No se oyen ya las voces! Grito desesperadamente. El barco pasa.

Lloroso, impotente, lo evidencio: las sirenas no cantaron para mí...

«El canto de las sirenas» (La desaparición de Fabricio Montesco, 1977)

Volvemos a encontrar a un Odiseo como el de Dante, que huye de sí mismo y de todo su pasado y desea conscientemente perderse. Campos intensifica su amargura, su pérdida de todos los valores que lo habían guiado: el héroe «muere de tristeza y rencor» y sabe que el funesto encuentro con las sirenas no le supondrá sino «un pretexto más para la tristeza». El atisbo de ilusión que aún conservaba el personaje de Torri está prácticamente ausente en este Odiseo que ha depositado sus últimas esperanzas en su fatídica entrega a las sirenas. Toda la primera parte del texto parece una amplificación de aquella declaración del Odiseo de Torri que se proclamaba «resuelto a perderse». Sin embargo, su nave también pasa de largo ante una isla de la que no sale canto alguno, cerrándose el microrrelato con la misma sentencia que el de Torri: «las sirenas no cantaron para mí». La transformación del episodio en emblema de la amargura y la frustración ha sido llevada al extremo.

José de la Colina, español criado en México, atribuye a sus sirenas la capacidad de hechizar aun cuando callan, pues son capaces de seducir atacando al oído y también a la vista:

Otra versión de la Odisea cuenta que la tripulación se perdió porque Ulises había ordenado a sus compañeros que se taparan los oídos para no oír el pérfido si bien 
dulce canto de las sirenas, pero olvidó indicarles que cerraran los ojos, y como además las sirenas, de formas generosas, sabían danzar...

«Las sirenas» (Tren de Historias, 1998)

De nuevo una parodia del hipotexto de $O d$. XII se presenta bajo la forma de comentario erudito, simulando metatextualidad. De la Colina habla de otra versión de la epopeya ajena a la canónica de Homero donde los hombres de Ulises fueron derrotados por las sirenas por medio de su atractiva danza. El foco está sobre el colectivo de griegos; no sabemos si Ulises se perdió también o si se salvaría por estar atado al mástil. Si en otros textos de esta sección las sirenas no cantan por desprecio al héroe, o porque notan que los viajeros se han tapado los oídos, en esta versión no es suficiente esa precaución, pues las criaturas marinas, no pudiendo usar sus voces hermosas, se sirven de sus cuerpos atrayentes, cuya sensualidad venía siendo muy ponderada desde la Edad Media.

El último minicuento de este apartado es una composición muy reciente de Antonio Jesús Cruz. Igual que Elizondo, este argentino dedica al propio Torri su peculiar versión de «A Circe». Dos son las innovaciones: la estructura epistolar y el éxito del protagonista en su proyecto.

Querida Circe:

Para Julio Torri

A pesar de tus recomendaciones no me hice amarrar al mástil cosa de la que nunca habré de arrepentirme. No imaginas lo maravilloso que es compartir, día a día, la misteriosa y sorprendente cotidianeidad de una sirena.

«Carta 2» (Cuaderno de microrrelatos, 2010)

Cruz mantiene la alocución en estilo directo a la diosa, pero sustituye el discurso oral por la forma de misiva. En ella el viajero innominado que reconocemos como Odiseo informa a Circe a posteriori sobre sus andanzas con las sirenas ${ }^{50}$. Como Torri y todos sus seguidores, Cruz reelabora el episodio desde un enfoque irónico, pero frente al fracaso final que teníamos en Torri y Campos y frente a la victoria decepcionante en Elizondo, esta vez el protagonista afirma triunfante que ha valido la pena desobedecer a Circe y disfrutar de la tentación.

\subsection{Circe amante y maga}

El personaje de Circe, al margen de Odiseo o con Odiseo en segundo plano, inspira microrrelatos que desarrollan alguna de las facetas sugeridas en Homero y perfiladas por los autores posteriores: está presente su rol de maga o de amante, y este último puede recibir connotaciones más románticas, eróticas o humorísticas.

Entre los microcuentos sobre la diosa más conocidos se encuentra "Circe», de Agustí Bartra, español exiliado en México. Aunque este texto aparece en las

50 En Luciano $V H$ II 35, 7-16 tenemos un texto similar al de Cruz en la forma y el contenido: Odiseo escribe a Calipso una carta donde expresa su arrepentimiento por haber rechazado la vida eterna y feliz que la ninfa le ofrecía a su lado y haber optado por regresar con Penélope. 
colecciones de microrrelatos desde que Edmundo Valadés lo incluyó en su antología El Libro de la Imaginación (1984), en realidad es un pasaje extraído de la obra extensa Odisseu, que se publicó en 1953 en catalán, y dos años después en castellano. El episodio de Circe, en forma dialogada ${ }^{51}$, se convierte en una escena emotiva y sentimental protagonizada por una mujer sensible y vulnerable. El fragmento de este episodio que pasó a transmitirse como microcuento forma parte de un intenso monólogo lírico que pronunciaba la diosa:

No hay sueños en mí, Ulises. No proyecto sombra sobre cosa alguna. El mundo es como una rueda radiante que comienza a girar cada mañana cuando abro los ojos. ¡Es todo tan sencillo! Un pájaro atraviesa el cielo: vuela, nada más. Una herramienta es brillante y dura: ha sido hecha por el ingenio. El mar está siempre despierto; las piedras duermen siempre. Yo no sueño, Ulises: cuento: una brizna, las estrellas, el aroma del heno, la lluvia, los árboles. Y como no quiero repetir nada, a nada le pido permanencia. La vida es como el agua: tócala con la mano abierta y la sentirás vivir, siempre igual en su fuga. Pero si aprietas la mano para cogerla, la pierdes. Mucha gente ha pasado, de muchas leyes y distintos países, por esta casa a orillas del mar. Y en cada uno la felicidad tenía un nombre diferente; pero se trataba siempre de alguna vieja y arrugada historia que llevaban a cuestas. ¡Quédate, Ulises!

«Circe» (Odisseu, 1953/ El libro de la imaginación, 1984)

Esta reelaboración contrasta con las frías separaciones de la diosa y el héroe en Od. X 569-574 y XII 150-152. Ya hemos tratado acerca de esa tradición de revisiones sentimentales del episodio de Eea con reminiscencias del Aen. IV ${ }^{52}$. La Circe de Bartra, dotada de una hondura psicológica poco común en los modelos, revela a un Ulises mudo sus sentimientos íntimos y una concepción de la existencia muy horaciana, sujeta al tempus fugit y al carpe diem, que le sirve como argumento para proponerle que olvide el vó $\tau$ to y aproveche el instante con ella. Si Calipso en la Odisea razonaba que Penélope no era más que una mortal y que ella, una diosa, podía otorgar a Odiseo la inmortalidad (V 206-213), la Circe de Bartra ofrece vivir el presente, disfrutar del tiempo efímero. Las abundantes pausas del soliloquio de Circe contribuyen a poner de manifiesto su turbación. Se detecta también en este caso un uso emblemático del tema para representar la tragedia de desperdiciar el amor y los fugaces deleites de la vida.

Marco Antonio Campos firma una inusitada e inquietante variación del pasaje homérico de la llegada a Eea expuesta desde el punto de vista de un personaje nuevo.

Cuando llegué a la isla, y sabiendo mi destino, quise ir a su casa a buscarla. Yo, en la playa, rogaba a los dioses por mirarla lo más pronto posible. Odiseo, el

51 De difícil adscripción genérica — sus partes están alternativamente en forma dramática, poética y narrativa— es una reescritura de la Odisea centrada en los sentimientos, particularmente la nostalgia del exiliado. La forma dramática para el episodio de Circe puede deberse al influjo del Ulises de Joyce o de los Diálogos con Leucó de Pavese. Sobre el Odisseu de Bartra $c f$. García Gual (2006: 275-279).

52 Estaba en Ovidio (Rem. 263-288), en Lope (La Circe) y Calderón (El mayor encanto, amor); en los Diálogos con Leucó Calipso («L'isola») y Circe («Le streghe») se duelen por la imposibilidad de retener a Odiseo. 
más astuto de los hombres ${ }^{53}$, me puso a la cabeza de la expedición. Llamándome aparte, me recomendó un gran cuidado. Yo le dije que sí; pero él sabía desde hacía mucho tiempo mi cruel hado. Pero, ¿quién tiene la culpa de mis errores? Los dioses han trazado mi vida como una flor desgarrada. Ellos, más que este frágil vaticinio, son culpables del infierno que he vivido. A lo lejos, detrás de la arboleda de los robles, se mira en un límpido valle, la casa de piedras pulidas de la diosa. Camino más rápido que mis compañeros. Las últimas ramas del sol acarician mi rostro como los dedos de la mujer amada. Estoy solo; nunca he estado más solo en esta tierra. Hoy enfrento al fin mi condición definitiva. Atravieso la arboleda de los robles y los leones y los lobos anuncian mi llegada a la mujer del sueño. Recargada en la puerta, ella, la diosa, me repite: «Oh Laertes, te esperaba, es inútil, la cabeza de Odiseo será hoy la cabeza de la piara».

«Circe» (La desaparición de Fabricio Montesco, 1977)

Se reconstruye el primer contacto de los itacenses con Circe, que en $O d$. X era narrado en primera persona dos veces: primero dentro del extenso relato de sus peripecias que hace Odiseo a los feacios (vv. 210-232), y seguidamente en boca de Euríloco, que lidera la expedición al palacio de Circe y cuenta sus consecuencias a Odiseo (vv. 251-260). Campos selecciona sólo la secuencia de la llegada de los griegos a la morada de la diosa, (aquí sin animales encantados ni canto atrayente de Circe), y la interrumpe justo antes del hechizo metamórfico. Habla en primera persona un compañero de Odiseo cuyo carácter es muy diferente al del desconfiado Euríloco, que evitaba penetrar en el palacio de Circe. Este viajero, que se arroga todo el protagonismo ante la ausencia casi total del héroe, conoce de antemano lo que va a suceder, e insiste en cumplir su ineludible hado, el cual parece haberle sido revelado por medio de sueños. Sabe que ha de enfrentarse «a su condición definitiva», y se encamina hacia su infausto final con la misma actitud resignada y fatalista de esos Odiseos de Torri y el propio Campos que se lanzan a las destructivas sirenas ${ }^{54}$. Sólo en la frase final del relato, cuando aparece Circe - que no es nombrada sino en el título- descubrimos que el personaje se llama Laertes, y que también la diosa sabe que el destino de todos ellos — incluido Odiseo — será formar parte de su piara.

De tono muy distinto es la breve y punzante evocación del tema de Circe en el siguiente microcuento de Marco Denevi:

\section{Al menor descuido de Circe, los amantes se le transformaban en cerdos. «El hombre, animal lujurioso» (Falsificaciones, 1984)}

En esta composición tan sintética salta al primer plano la relación del texto con el paratexto. El microrrelato consta de una única oración que parodia el mito de Circe, y el título es una adaptación también paródica de la célebre sentencia aristotélica $\varphi v ́ \sigma \varepsilon 1$

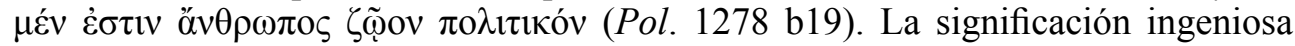

53 Remite a los epítetos que en la Odisea recalcan la sagacidad del protagonista: $\pi$ o $\lambda$ $\tau \rho o \pi$ os (Od. I 1, X 330),

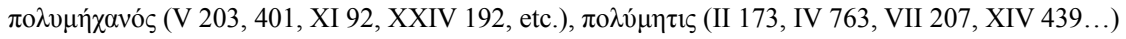

54 De hecho, llama la atención la cercanía de este microcuento al primero del mismo autor que hemos visto aquí, «El canto de las sirenas»: ambos tienen idéntico comienzo («Cuando llegué a la isla...») e idéntico tono siniestro y fatídico; en los dos habla un narrador en primera persona que se sabe condenado al desastre. 
viene dada por la relación entre texto y paratexto: sin el título estaría incompleta. Jugando con las connotaciones de suciedad e impudicia que tiene el cerdo, la historia homérica se subvierte: los amantes de Circe se convierten en cerdos sin que ella lo pretenda. Veíamos que desde la Antigüedad muchos autores, apoyándose en estas implicaciones que nuestra cultura atribuye al cerdo, habían interpretado las metamorfosis de $O d$. X como una alegoría de la degradación del hombre que se deja arrastrar por la lujuria: ésta era la visión que triunfó entre los cristianos, particularmente desde el tratamiento de Boecio. El texto de Denevi sería una réplica humorística tanto a la aventura de la Odisea como a sus exégesis moralistas ${ }^{55}$.

Otro texto de Denevi se ocupa asimismo del personaje de Circe y sus avatares eróticos, aplicando idéntico procedimiento humanizador y jocoso:

Enterada, por los frescos pompeyanos, de que los sátiros poseían un miembro viril bífido, con el que satisfacían a las ninfas por ambos conductos a la vez, Circe les contaba a sus amigas: «No lo creerán, pero anoche me acosté con un sátiro». Una de las amigas sonrió:

«Te creo, querida. Vi cuando los dos entraban en tu casa». «Sátiros caseros» (El jardín de las delicias. Mitos eróticos, 1992)

Venimos mostrando que la imagen de Circe como depredadora sexual no es extraña en las reelaboraciones homéricas, sobre todo desde la exégesis moralista. Su enigmático poder para someter a hombres y animales y su idilio con Odiseo dieron pie a desarrollos del episodio que recalcaban el erotismo y la lascivia de la maga. Dentro de esta tradición que resalta la concupiscencia de Circe podemos citar la aventura que ocupa los capítulos CXXV-CXL del Satiricón de Petronio sobre una fogosa dama llamada Circe a la que Encolpio no logra satisfacer, numerosas interpretaciones cristianas como la de Pérez de $\mathrm{Moya}^{56}$, La Circe de Lope; La navegación de Ulises y Los encantos de la Culpa de Calderón; el Capítulo 15 «Circe» del Ulises de Joyce, protagonizado por la prostituta Bella Cohen. Denevi saca a Circe de su contexto propio, el de las aventuras de Odiseo, e inventa un episodio completamente nuevo para la diosa homérica. La descontextualización que experimenta su figura, humanizada y actualizada, se completa relacionando a la divinidad griega arcaica con un elemento cultural de la civilización romana: las pinturas eróticas de las casas de Pompeya. El pintoresco dato acerca de los sátiros entronca con la tradición del bestiario, tan del gusto de los microrrelatistas ${ }^{57}$.

Raúl Renán, en un hipertexto brevísimo e irónico, ejecuta una prolongación de la secuencia de $O d$. X de las metamorfosis marcada por el humor cínico y realista.

Gracias a mi mente que se mantuvo humana, a salvo de los hechizos de la diosa,

55 Una Circe humana y prudente con amantes embrutecidos como bestias aparecía en Pavese, «Le streghe».

56 «Mujer de tan estremada hermosura, cuanto llena de tanta lascivia, que se ayuntaba con todos los que por allí pasaban, porque a todo hombre que la veía provocaba al pecado sensual.» (Philosofía secreta IV, XLVI)

57 Los sátiros en la iconografía antigua suelen ser itifálicos. En el lupanar de Pompeya hay un fresco del dios Príapo con un miembro doble, aunque tampoco es ésta su representación más habitual. 
logré escabullirme, y al llegar a las afueras cayó sobre mí un puerquero que me sometió venciendo mis chillidos. «Circe» (Los silencios de Homero, 1998)

Coincide «Circe» de Renán con el microrrelato homónimo de su paisano Marco Antonio Campos en varios detalles: el título, el tema de las metamorfosis en cerdos (el relato de Campos desarrolla los instantes previos, el de Renán los posteriores) y la voz narrativa en primera persona que corresponde a un compañero de Odiseo (en Renán sin nombre). El protagonista tiene un irónico destino: transformado en cerdo, conserva sus facultades intelectuales — dato tomado de $\mathrm{Od}$. X 240- que le permiten huir, pero habiendo conseguido escapar de la diosa maga, es capturado por otro enemigo, un porquero, más prosaico pero igual de peligroso. De las dos oraciones que componen esta pieza, la primera mantiene los sucesos dentro de las coordenadas épicas (la diosa, el hechizo, la huida), y la segunda introduce componentes pedestres (el porquero y el gorrino que chilla) que colisionan con el universo heroico y mítico.

Finalizamos la sección dedicada a la figura de Circe con la ampliación del final de la aventura de Eea que realiza Diego Muñoz Valenzuela:

La preciosísima Circe estaba aburrida de la simplicidad de Ulises. Si bien era fogoso, bien dotado y bello, la convivencia no daba para más. Solía convertirlo en perro para propinarle patadas, y él sollozaba y le imploraba perdón. Lo transformaba en caballo para galopar por la isla de Ea, fustigándolo con dureza. Lo transmutaba en cerdo para humillarlo alimentándolo con desperdicios. Volvía a darle forma humana para hacer el amor, y volvía a fastidiarse con su charla insulsa. Por fin lo expulsó del reino, le restituyó su barca y sus tripulantes y lo dotó con alimentos para un largo viaje. «Vete y no vuelvas», ordenó con voz terminante al lloroso viajero, «y cuenta lo que quieras para quedar bien ante la historia». Después sopló un hálito mágico para hinchar la vela de la embarcación.

«Rehabilitación de Circe» (Las nuevas hadas. Microrrelatos fantásticos, 2011)

El autor chileno se suma a la técnica de presentar un hipertexto como corrección de mentiras o inexactitudes de su hipotexto. Lo que hace es desarrollar una parte del episodio silenciada en Homero, que no daba información acerca del año que Circe y Odiseo pasan juntos ${ }^{58}$. Extremando la visión de una Circe inteligente y un Odiseo simple que hemos señalado en modelos como Plutarco y Pavese, su Circe, ingeniosa y poderosa, se dedica a humillar al desesperante Ulises transformándolo en toda clase de animales — no sólo en cerdo - y maltratándolo, hasta que se aburre de él y lo expulsa de su isla, contribuyendo a su partida con un viento favorable (estaba en Od. XI 8-10 y XII 150-152). Ella misma le sugiere que invente una historia que lo deje en mejor lugar: sería la que ha transmitido la Odisea.

58 Todo el periodo es sintetizado en dos únicos versos: «Allí pasamos todos los días de un año entero/ consumiendo

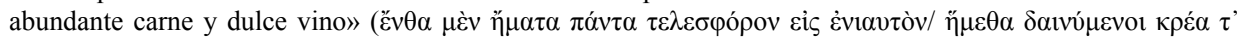

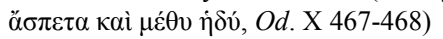




\subsection{Sirenas antiguas y nuevas sirenas}

Son muchos los agudos y sutiles tributos al tema de las sirenas en el microrrelato. La materia clásica se innova desde ópticas originales y variadas, donde difícilmente se pueden señalar más denominadores comunes que el canto como elemento definitorio de las sirenas. En nuestros textos alternan las arcaicas sirenas griegas con otras sirenas nuevas adaptadas a la realidad contemporánea. Ésta es sólo una modesta muestra de la fecundidad del mito en la minificción hispanoamericana ${ }^{59}$.

Comenzamos con un relato hiperbreve de la argentina Ana María Shua, que se propone esclarecer el rasgo esencial de las sirenas, el canto mágico:

Lo cierto es que las sirenas desafinan. Es posible tolerar el monótono chirrido de una de ellas, pero cuando cantan a coro el efecto es tan desagradable que los hombres se arrojan al agua para perecer ahogados con tal de no tener que soportar esa horrible discordancia. Esto les sucede, sobre todo, a los amantes de la buena música.

$$
\text { «¿Sirenas?» (La sueñera, 1984) }
$$

Es éste otro ejemplo de cómo los silencios de la fuente homérica inspiran imaginativas soluciones para completar las lagunas de información y las incógnitas que dejan las epopeyas. Shua inventa una perspicaz y jocosa explicación para el nunca del todo aclarado hechizo de las sirenas ${ }^{60}$. La mayoría de fuentes antiguas señalan, siguiendo a Homero, que el canto de las sirenas retenía a los navegantes, que sin ser capaces de alejarse de su isla morían en este lugar, plagado por ello de huesos humanos (Od. XII 45-46, Aen. IV 864-865, etc.). En algunas fuentes los navegantes se arrojan al agua para acudir al encuentro de las criaturas hechizantes ${ }^{61}$. La creación metatextual e irónica de Shua subvierte este último dato: si el canto de las sirenas hacía a los hombres arrojarse al agua no era por su belleza, sino porque era insoportablemente feo. «iSirenas?» se ciñe a este único aspecto: no podemos saber si estamos ante las sirenas aviformes grecolatinas o si son las mujeres-pez de la tradición posterior.

En un cuento de una sola frase el mexicano Edmundo Valadés juega con la polisemia del término «sirena»:

Esas sirenas enloquecidas que aúllan recorriendo la ciudad en busca de Ulises. «La búsqueda» (De bolsillo, 1989)

El texto está compuesto de una única imagen, un destello brevísimo, que conlleva sin embargo una alteración múltiple del tema tradicional. La

59 Perucho ha editado dos colecciones de microcuentos sobre sirenas: $c f$. Perucho (ed.) (2008 y 2013).

60 La misteriosa naturaleza del canto de las sirenas ha generado durante siglos diversas propuestas de literatos y exegetas; Spina (2007: 3-20) recoge varias.

${ }_{61}$ Así en A.R. IV 912-919, donde el argonauta Butes se tira al mar para acudir a la isla, pero lo salva Afrodita. También aparecía esta amenaza en «Jasón» de Anderson Imbert. 
identificación de las sirenas con el mecanismo automático para emitir avisos sonoros implica una cosificación y una desmitificación de estas figuras, así como una descontextualización que las traslada desde su remoto universo fabuloso hasta la urbe moderna, y las convierte en una especie de seres ávidos, enloquecidos y aullantes, que seguirían persiguiendo al héroe que logró escapar de ellas veintiocho siglos atrás. En esta reescritura irónica las sirenas, procedentes de un universo maravilloso, pierden su forma de mujeres, y hasta de aves o peces, y su canto dulce y atrayente se transfigura en la violenta y desabrida alarma que suena en las ciudades modernas.

David Lagmanovich firma un texto inspirado por Valadés. Recurriendo a un idéntico procedimiento descontextualizador, el argentino despoja a las sirenas de su esencia sobrenatural, las sitúa en la cotidianeidad moderna y las relaciona con las alarmas de los vehículos de la policía:

De su isla maravillosa las sirenas emigraron a la ciudad, donde los hombres no comprendieron su naturaleza mágica. Por eso dieron su nombre al ulular inmisericordioso de los coches policiales, mensajeros de todas las desgracias. Las verdaderas sirenas, que en pro de la convivencia entre minorías ya habían eliminado sus colas de pez, quisieron evitar ser delatadas por su canto. Desde entonces se mantienen silenciosas, viven en casas de departamentos y aportan a la seguridad social.

«Sirenas emigrantes» (Los cuatro elementos, 2007)

Estamos ante una prolongación no ya necesariamente de la Odisea, sino en general de los hipotextos que transmiten la leyenda de las sirenas. Más aún que el de Valadés, el microrrelato de Lagmanovich resalta el violento choque entre la delicada fantasía y la vulgar realidad: estas sirenas tampoco cantan porque se ven desposeídas de todos sus atributos maravillosos — su isla, su canto, su naturaleza híbrida - y se ocultan en una existencia gris y urbana entre hombres que no las comprenden. La parodia es extremadamente amarga, y en este texto son ellas quienes sufren una estrepitosa derrota contra un mundo prosaico al que tratan de adaptarse. La relación emblemática entre estas desdichadas sirenas y la tragedia del expatriado se declara abiertamente en el paratexto.

El original microrrelato de otro argentino, Raúl Brasca, se aproxima a la modalidad del bestiario. Es la única composición que recrea a una sirena aviforme, y la enfrenta en un insólito combate a una sirena pisciforme:

La monstruosa sirena griega posó sus garras sobre la roca que emergía del agua, plegó las alas y comenzó a cantar. La barca puso proa hacia ella.

Una sirena diferente, con una poderosa cola de pez, surgió del mar a popa y se tendió en otra roca no muy distante. Era hermosa y tenía pechos grandes. Sus cabellos verdes resplandecían al sol. Cuando hizo oír su canto, la barca invirtió el rumbo y fue a su encuentro. 
La griega no se arredró. Ella pertenecía al aire y el aire produjo una brisa suave que llenó con su voz los oídos de los tripulantes y llevó lejos la de su rival. Los remeros bogaron de nuevo hacia la emplumada, aunque por poco tiempo, porque el mar respondió con una corriente que orientó la nave otra vez hacia la bella.

Fue así como el duelo de sirenas se hizo duelo de elementos.

Cuando la barca amenazaba ir hacia la griega, la corriente se volvía más vigorosa y no la dejaba avanzar. Cuando parecía desplazarse en el sentido opuesto, un vendaval frenaba las olas. Pasaron los días. Los remeros, hambrientos y exhaustos, languidecían sin lograr que la nave se desplazara. Las dos sirenas, fieles a sus dioses tutelares, seguían cantando. Cantaron sin cesar hasta mucho después de la muerte del último tripulante. Sólo cuando la vejez y el ajetreo del viento y el agua hundieron la barca, la griega remontó vuelo y la bella volvió a las profundidades. Sin embargo, sus voces mágicas aún resuenan en ese lugar.

«Duelos» (Las gemas del falsario, 2008)

Brasca contrapone las dos imágenes de las sirenas que la tradición había transmitido ${ }^{62}$ : la «monstruosa» de los textos griegos, mezcla de mujer y ave, y la que se impone desde el Medievo, la «hermosa» ninfa acuática, híbrido de mujer y de pez, con «pechos grandes»y «cabellos verdes». El autor las vincula respectivamente a los elementos del aire y del agua. Una y otra poseen el mismo don del canto mágico, y enfrentan sus habilidades para desgracia de una nave que zozobra entre ambas fuerzas. Al no obtener la victoria ninguna de las dos, mueren todos los tripulantes y los dos monstruos se retiran a sus lugares de procedencia. Las sirenas son protagonistas absolutas de esta original historia, que nada permite saber acerca de sus víctimas o la localización espacial y temporal de este duelo. Esta creación se aleja de la escritura transtextual para acomodarse más bien en la literatura fantástica mediante el juego con la doble iconografía de la sirena en su tradición multisecular.

Hasta aquí hemos podido comprobar la rica tradición de las sirenas en la forma del microrrelato. Para concluir, veamos un texto donde el mexicano Javier Perucho ejecuta un genial ejercicio metaliterario sobre el tema. Apoyándose en esta cadena de transtextualidad, su minificción evoca diferentes lecturas del episodio de Ulises y las sirenas desde Homero hasta el cuento hiperbreve hispanoamericano.

Sépanlo bien, escribanos: No cantamos para él porque nos difamaron diciendo que olíamos a pescado, que formábamos tropel entre las causas perdidas, igualándonos con las suripantas, ija! ¿Que Ulises nos poseyó ingeniosamente para ya no volver a nuestro lecho? Ensueños de marino en alta mar y patrañas de poeta.

Si supieran. Ulises apenas desembarcó, se quedó dormido por cansancio. Contó luego por ahí que se amarró al mástil mientras le untaban cera en el caracol de los oídos y ordenaba a su tropa marinera que no lo dejaran atracar en esta ínsula de playas apacibles y remansos de mar si el vórtice de nuestro canto lo atrapaba, infundios que luego propaló ladinamente entre sus rapsodias aquel poeta invidente y con él, ustedes.

62 Borges, que puede haber servido de modelo, se había encargado de ambas en el capítulo «Sirenas» de su Libro de los seres imaginarios. 
Sí, apenas salmodiamos para aplacar su sueño de náufrago a la deriva. Y según la buena palabra de la nereida bicaudal que lo velaba, dormía agitado, lubricado por la esposa tejedora, Penélope, el nombre que susurraba en su descanso de alcoba silente.

Antes de volver a su barco, desvaneció con agua dulce el sudor agrio, las costras de sal adheridas a su torso y su imberbe barba pilosa.

El testimonio de sus libros apenas recoge esos infundios de marinero célibe.

«Silencio de alcoba» (Anatomía de una ilusión, 2016)

La composición adopta la forma de discurso en estilo directo que las sirenas dirigen a los «escribanos» que tantas veces han reescrito y siguen reescribiendo su historia, para defenderse de las infamias que la literatura ha vertido sobre ellas. Sigue Perucho esa tendencia consolidada en las reescrituras posmodernas de mitos de dar la palabra a personajes marginales para que aporten un punto de vista que nunca se ha escuchado. Las sirenas afirman no haber cantado, como en las versiones de Torri o Kafka - el paratexto de Perucho versiona los de los cuentos de Kafka y Brecht - porque se sentían ofendidas por las alusiones a su mal olor («Aviso» de Elizondo) y su identificación con lo vano o quimérico (la expresión «escuchar cantos de sirenas») o con las mujeres de vida disoluta (motivo mil veces repetido desde la exégesis moralista antigua hasta la literatura moderna); niegan asimismo que Ulises las poseyera para después abandonarlas («La sirena inconforme» de Monterroso). El héroe de nuevo se revela como un embustero que engañó al «poeta invidente» ${ }^{63}$ contándole la historia de la cera en los oídos y el mástil, cuando lo cierto fue que atracó en la isla de las sirenas — de «playas apacibles y remansos de mar», en vez de esa pradera cubierta de huesos humanos de las fuentes antiguasy se durmió apenas arrullado por el canto de las sirenas que velaban su sueño. Se pone en cuestión el heroísmo del protagonista de la Odisea, que no vivió las aventuras que se le atribuyen y no era más que un ordinario «marinero célibe» que soñaba con su «esposa tejedora» ${ }^{64}$. La naturaleza acuática y pisciforme de estas sirenas bondadosas pero vilipendiadas se comunica con la expresión «nereida bicaudal».

\section{Conclusiones}

Esta recopilación de microcuentos nos permite apreciar las líneas comunes y la riqueza y multiplicidad de tratamientos en el tema de Circe y las sirenas desde principios del siglo xx hasta nuestros días: abarcamos un periodo de 100 años en el cual tienen lugar el nacimiento, el desarrollo y el apogeo de la minificción. El tono desenfadado de la minificción y su forma breve y aforística contribuyen a subrayar una impresión de género menor que no se toma a sí mismo en serio. Pero la muestra

63 Esta idea procede de la tradición antihomérica de la Antigüedad. Ya Jenófanes de Colofón acusaba a Homero y Hesíodo de mentirosos (fr. 10-11); Píndaro afirmaba que Homero había exagerado la astucia de Odiseo ( $N$. VII 17-23); Platón fue el portavoz más destacado de esta corriente, con críticas a la épica arcaica como las de $R$. 377d y ss.; según Filóstrato, Homero llenó sus epopeyas de mentiras porque el fantasma de Odiseo le había dicho que sólo le contaría la historia de Troya si lo elogiaba (Her. 727.22-728.21).

64 Es una imagen semejante a la del «condenado y cauto provinciano» del cuento de Brecht. 
que hemos analizado revela que estamos ante una forma literaria que encierra enorme sensibilidad ante la tradición cultural, amor bibliográfico y agudo ingenio.

Los autores toman los motivos homéricos incrementados con los rasgos que una tradición de muchos siglos les había otorgado. La imagen de Circe y las sirenas predominante en Occidente ha sido la de unos personajes femeninos mágicos, fascinantes y malignos: los microcuentistas suelen respetar esa visión aun para innovarla con el fin de lograr la originalidad y la sorpresa.

Los escritores de minificción, respondiendo a las exigencias de la Posmodernidad literaria, someten a mutación las bases de nuestra cultura, cuestionan los textos canónicos, relativizan sus verdades y desplazan el foco de atención de las visiones dominantes a las marginales. Este proceso se lleva a cabo alterando los sucesos del hipotexto y los acercamientos interpretativos, dando voz a las figuras secundarias, relegadas o denostadas - Circe, las sirenas, Penélope, los compañeros de Odiseo-y adoptando la apariencia de comentario o exégesis («en otra versión», «la verdadera historia», etc.) para polemizar con los patrones reconocidos, en este caso Homero. Las gestas épicas se ponen en duda, y a veces Odiseo o el mismo Homero son acusados de ocultar la verdad; así sucede en textos como «Silencio de sirenas» de Kafka, «La tela de Penélope o quién engaña a quién» de Monterroso, «Rehabilitación de Circe» de Muñoz Valenzuela o «Silencio de alcoba» de Perucho. Mediante tal polifonía, se entabla un diálogo crítico con Homero, y sus mitos se enriquecen, se refutan, se transforman.

Asistimos a la desacralización del mito grecolatino y a la resemantización de personajes y aventuras de la mitología clásica. El microrrelato emprende la reescritura de la tradición cultural para subvertirla y construir con sus elementos alterados una nueva imagen de la realidad. La actitud irreverente hacia los textos encumbrados surge como «consecuencia de un sistemático ejercicio desjerarquizador» ${ }^{65}$. Los autores hacen gala de una filosofía vital escéptica y cínica, y el tono de sus versiones clásicas es antiépico: parodia, irreverencia, incredulidad, distanciamiento, descontextualización. Las grandes historias de héroes y dioses se ven despojadas de solemnidad y pretensión, trasladadas a las coordenadas de la actualidad, con el consiguiente choque de ideologías y valores, y rebajadas a la tosca realidad ${ }^{66}$. En este sentido son muy ilustrativas las minificciones sobre el motivo de las sirenas resentidas que no cantan: lo que la épica vio como heroísmo se lee ahora como arrogancia, lo que era cautela se interpreta como cerrazón e ignorancia. Esta actitud literaria, aunque privilegiada en la Posmodernidad, nace y se desarrolla en la Antigüedad grecolatina ${ }^{67}$.

Desde esta nueva óptica los personajes se humanizan y se actualizan, y la adaptación pasa casi siempre por la revalorización de lo femenino. Circe y las sirenas normalmente se rehabilitan - la primera depone sus páp $\mu \alpha \kappa \alpha$ y sus poderes y las segundas su canto mágico- y Odiseo se convierte en un antihéroe o en un hombre común. Si en Homero no había sido transformado por Circe y había vencido el canto de las sirenas, los mi-

65 Como explica Pollastri (2012: 1657-1658), con las estrategias menores que acuñaron las vanguardias (libertad, metatextualidad, humor, fragmentarismo...) se minan las estructuras de la tradición literaria occidental.

66 Esto no está reñido con la idea que plantea Noguerol Jiménez (1994: 217) de que estos textos llenos de fantasía y lirismo - aun cuando estos elementos se ven truncados - suponen una reacción contra el prosaísmo contemporáneo por parte de unos «creadores de nuevas mitologías».

67 Visiones satíricas de estos episodios de la Odisea tenemos ya en Esquilo (drama satírico perdido Circe), Anaxilao (en su comedia Neótide, fr. 22 K.-A.), Horacio (Sat. II 3 14-15), Priapeum LXVIII 19-28, Marcial (III 64), Plutarco (Grilo), Páladas de Alejandría (AP. X 50)... 
crorrelatos lo muestran degradado, vencido por las sirenas tanto cuando le cantan como cuando no lo hacen. Las aventuras épicas eran sobrias y concisas, pero precisamente por lo elípticas, abiertas a sugerencias y desarrollos. Ya en Homero Circe es amante (Bartra, Denevi), confidente o ayudante (Torri), y en cierto modo superior a Odiseo (Denevi, Muñoz Valenzuela), y Odiseo muestra esa seguridad en sí mismo que los modernos leen como soberbia y necedad (Monterroso, Denevi, Muñoz Valenzuela, Perucho...) y esa audacia y curiosidad - ya en la Odisea se expone al canto de las sirenas pudiendo haberse tapado los oídos - que inspira versiones como las de Torri, Elizondo y Campos. En cuanto a las sirenas, oscilan entre meros seres monstruosos (Brasca, Shua), féminas seductoras (Denevi, Cruz, de la Colina) y figuras trágicas e incomprendidas (Monterroso, Lagmanovich, Perucho). Las dos primeras visiones existen desde tiempos muy remotos, y la última es la que triunfa en las revisiones posmodernas.

Está en lo cierto Serrano Cueto cuando observa que los autores de microrrelatos se dedican de forma casi unánime a desacreditar a Homero, a contradecirlo y tildarlo directa o indirectamente de impostor. Con esto, según este autor, entran a formar parte de la corriente antihomérica ${ }^{68}$ - a la que nos hemos referido a propósito de la minificción de Perucho_-, encabezada por Platón y casi tan antigua como las propias epopeyas. Pero cada recreación de la épica homérica es, más allá de la sátira, una abierta demostración de admiración. Todas las parodias, reinterpretaciones y correcciones del vapuleado aedo forman parte de un ininterrumpido homenaje que empezó en la Antigua Grecia. Todos se han apropiado de los textos de Homero porque todos lo han sentido como un patrimonio propio.

\section{Bibliografía}

Aguirre Castro, Mercedes (1994), «El tema de la mujer fatal en la Odisea», CFC 4: 301-317. Álvarez Morán, M. ${ }^{a}$ Consuelo, e Iglesias Montiel, Rosa M. ${ }^{\text {a }}$ (coords.) (1999), Contemporaneidad de los clásicos en el umbral del tercer milenio: actas del congreso internacional de los clásicos. La tradición grecolatina ante el siglo XXI (La Habana, 1 a 5 de diciembre de 1998), Murcia.

Bakucz, Dóra (2016), Reescritura y falsificación: la significación palimpséstica en el microrrelato argentino, Madrid.

Bañuls Oller, José Vicente; Sánchez Méndez, Juan, y Sanmartín Sáez, Julia (eds.), (1999), Literatura Iberoamericana y Tradición clásica, Barcelona/Valencia.

Brioso Sánchez, Máximo (2012), «Las sirenas en la épica griega: de Homero a las Argonáuticas Órficas (I)», Habis 43: 7-26.

- (2013), «Las Sirenas en la épica griega: de Homero a las Argonáuticas Órficas (II)», Habis 44: 43-60.

Conchillo, Carlos, y Sánchez, José (1988), «Ulises y el silencio de las sirenas», La Balsa de la Medusa 5-6: 50-61.

Flawiá de Fernández, Nilda M. ${ }^{a}$, y Assis de Rojo, M. ${ }^{a}$ Estela (2008), «De mitos y de máscaras: Falsificaciones de Marco Denevi», en Flawiá de Fernández, Nilda M. ${ }^{\text {a, }}$ y Assis de Rojo, M. ' Estela, Ayres de familia: cercana lejanía de la cultura clásica en el Río de La Plata, Tucumán: 141-148.

68 Serrano Cueto (2015: 14). 
García Gual, Carlos (1999), «Sobre la reinterpretación literaria de mitos griegos: ironía e inversión del sentido», en Villanueva, Darío; Monegal, Antonio, y Bou, Enric (coords.), Sin fronteras. Ensayos de literatura comparada en homenaje a Claudio Guillén, Madrid: 183-194.

- (2006), «Ecos novelescos de la Odisea en la literatura española», en Valverde Sánchez, Mariano; Calderón Dorda, Esteban, y Morales Ortiz, Alicia (coords.), Koinòs lógos: homenaje al profesor José García López, vol. 1: 275-284.

- (2014), Sirenas. Seducciones y metamorfosis, Madrid.

Genette, Gérard (1989), Palimpsestos. La literatura en segundo grado, C. Fernández Prieto (trad.), Madrid.

Hernández Mirón, Juan Luis (2010), «Manifestaciones de la estética posmoderna en la aparición y desarrollo del microrrelato», AnMal electrónica 29: 123-140.

Hofstetter, Eva, y Krauskopf, Ingrid (1997), «Seirenes», en Lexicon Iconographicum Mythologiae Classicae, Fondation pour la LIMC, tomo VIII.2, Zürich.

Jiménez San Cristóbal, Ana Isabel (2012), «Las Sirenas», en Bernabé Pajares, Alberto, y Pérez de Tudela Velasco, Jorge (eds.), Seres híbridos en la mitología, Madrid: 115-151.

Lagmanovich, David (2006), El microrrelato: teoría e historia, Palencia.

López Férez, Juan Antonio (ed.) (2009), Mitos clásicos en la literatura española e hispanoamericana del siglo $\mathrm{XX}$, Madrid.

Marinatos, Nanno (1995), «Circe and liminality: ritual background and narrative structure», en Andersen, Øivind, y Dickie, Matthew (eds.), Homer's World, Bergen: 133-140.

Noguerol Jiménez, Francisca (1994), «Inversión de los mitos en el micro-relato hispanoamericano contemporáneo», en Gómez Canseco, Luis (ed.), Las formas del mito en las literaturas hispánicas del siglo XX, Huelva: 203-209.

Omil, Alba (2000), «La figura de Circe y la transtextualidad», en Omil, Alba, El microrrelato y otros ensayos, Tucumán: 63-71.

Pedrosa Bartolomé, José Manuel (2015), «Las sirenas, o la inmortalidad de un mito (una visión comparatista)», Revista murciana de antropología 22: 239-300.

Pellicer, Rosa (1998), «El canto de las sirenas (textos hispanoamericanos)», Arrabal 1: 127-136.

Pépin, Jean (1976), Mythe et allegorie. Les origines grecques et les contestations judéochrétiennes, Paris.

Perucho, Javier (ed.) (2008), Yo no canto, Ulises, cuento: la sirena en el microrrelato mexicano, México D. F.

Perucho, Javier (ed.) (2013), La música de las sirenas, Toluca.

Pollastri, Laura (2012), «La vigilia de los signos: microrrelato hispanoamericano desde las vanguardias», en Couto-Cantero, Pilar; Enríquez Veloso, Gonzalo; Passeri, Alberta, y Paz Gago, José María (coords.), Proceedings of the 10th World Congress of the International Association for Semiotic Studies (IASS/AIS), A Coruña: 1649-1660.

Rahner, Hugo, (2003), Mitos griegos en interpretación cristiana, C. Rubies (trad.), Barcelona.

Roas, David (ed.) (2010), Poéticas del microrrelato, Madrid.

Serrano Cueto, Antonio (ed.) (2015), Después de Troya. Microrrelatos hispánicos de tradición clásica, Palencia.

Spina, Luigi (2007), «Cosa cantavano di solito le sirene? Quid sirenes cantare sint solitae», AOFL, Lettere speciale I: 3-20.

Zaïtzeff, Serge (2004), «Julio Torri revisitado», en Noguerol Jiménez, Francisca (ed.), Escritos disconformes. Nuevos modelos de lectura, Salamanca: 289-300.

Zavala, Lauro (2005), Cartografías del cuento y la minificción, Sevilla. 